بررسى آزمايشخاهى و عددى هيدروليك جريان در محل انشعاب رودخانهها (مطالعات موردى: انشعاب كرخه)

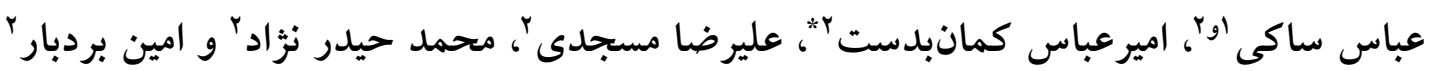

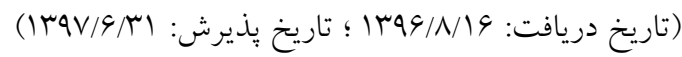

جكيده

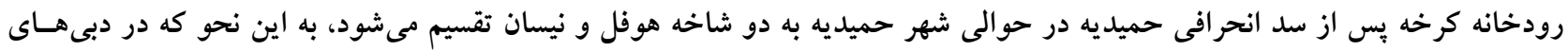

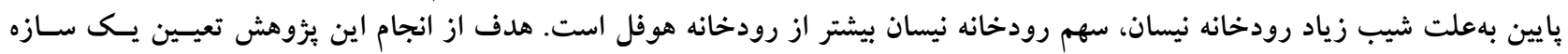

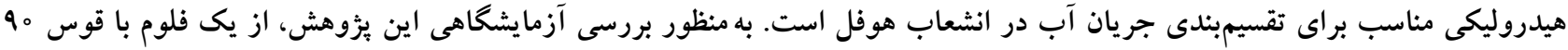

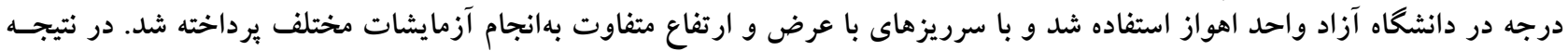

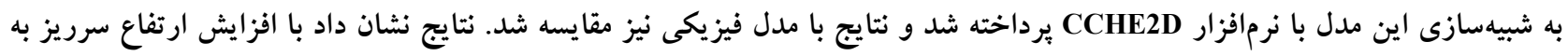

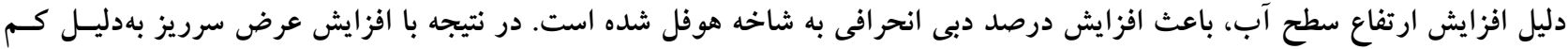

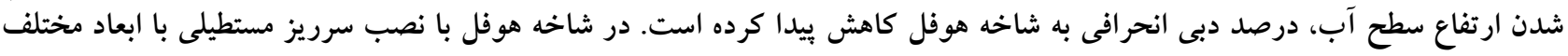

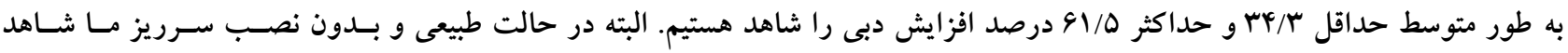

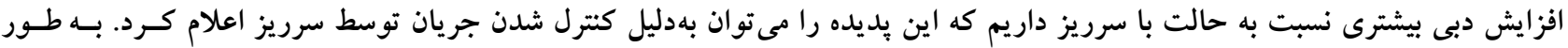

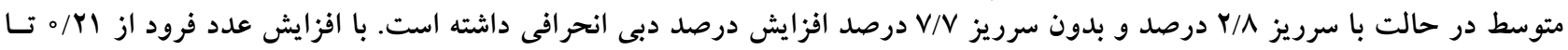

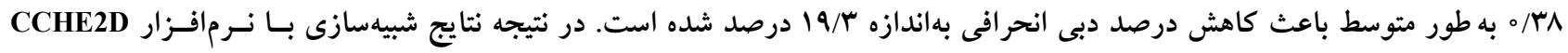

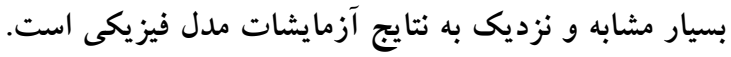

وازههاى كليدى: سرريز، انشعاب رودخانه، مدل فيزيكى، مدل رياضى، CCHE2D

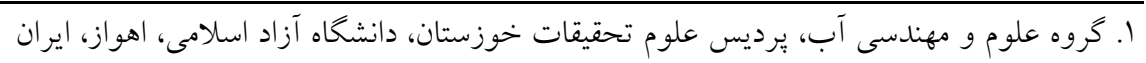

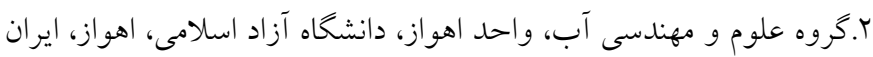

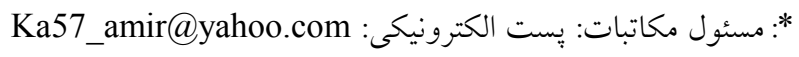




$$
\text { رسوبات انحر اف كمترى را شامل مىشود. }
$$

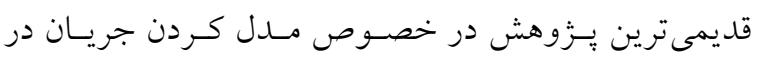

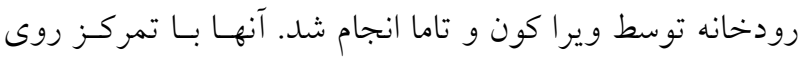

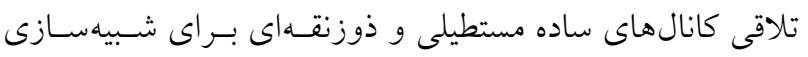

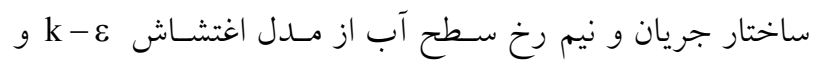
روش سريوش صـلب اسـتفاده كردنــــ ويسرا كـون و همكــاران روش كامل بيضوى را در مطالعه تلاقى 9 درجه غيرمتقـارن در

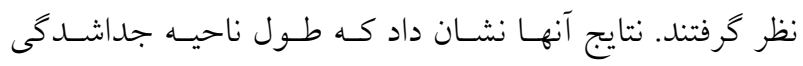
جريان حدود مب درصد كمتر از مقدار اندازه كيرى اسـت. دليـل اين كاهش طول را ناشى از يخشيدگى عددى، استفاده از شـكل

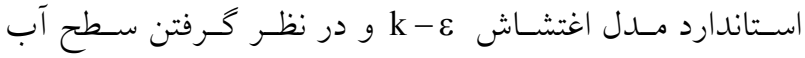

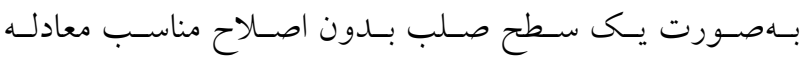

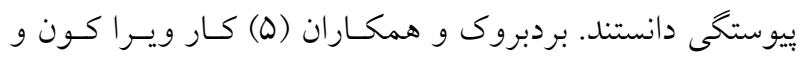

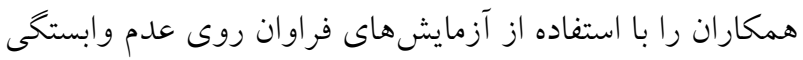

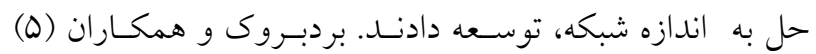
روى بررسى تأثير نسبت سـرعت، زاويـه تلاقس، درجـه تقـارن

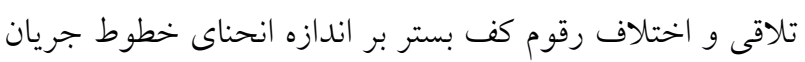

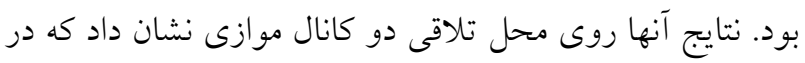

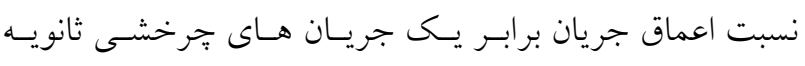

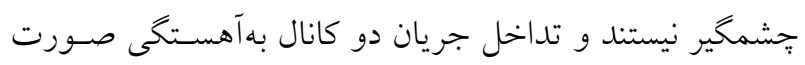
مى كيرد. با افزايش رقوم كف كانـال فرعى و در نتيجهـ كـاهش ونش

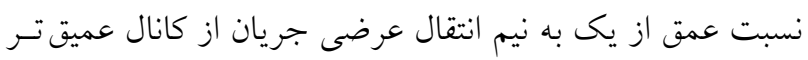

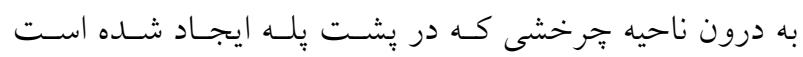

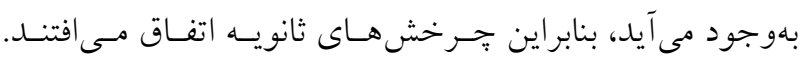

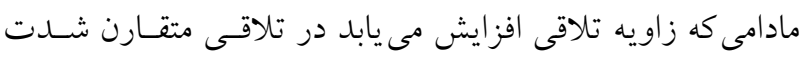

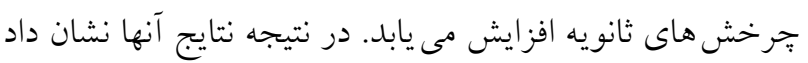

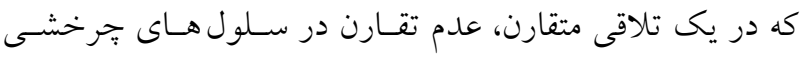

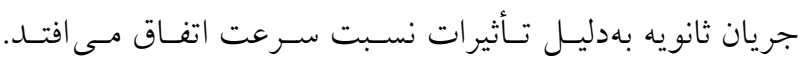

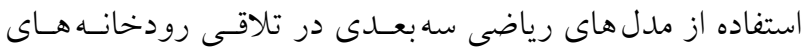
طبيعى توسط لين و همكاران (4 (1) و بردبروك و همكاران انجام شده است. لين و همكاران با كاربرد مدل براى تلاقى رودخانسه كاسكاسيا و كوير كه قبلاً توسط رودز و كنـورتى مطالعهـ شـده

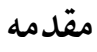
رودخانهها از ديرباز به عنوان يكى از اساسىترين منابع تـأمين آب

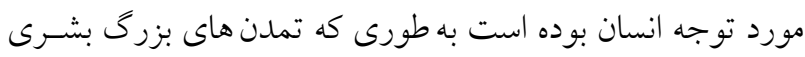

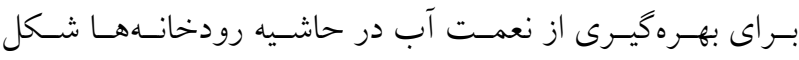

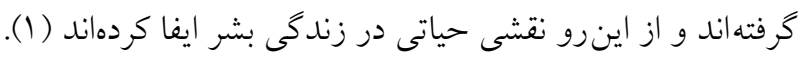

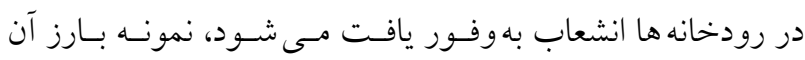

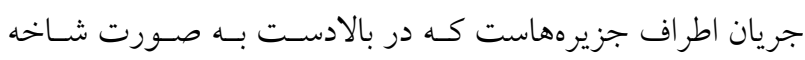
انحر افى و در بايين دست به صورت شاخه تركيبى اسـت. يكسى از

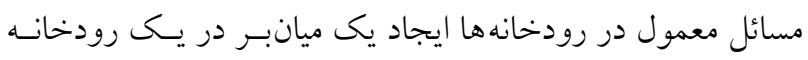

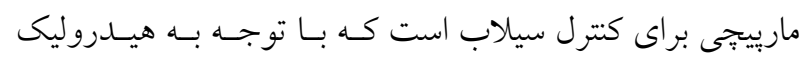

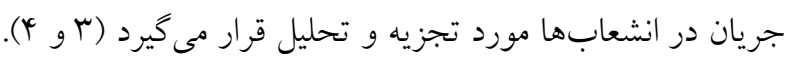

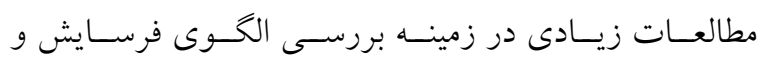

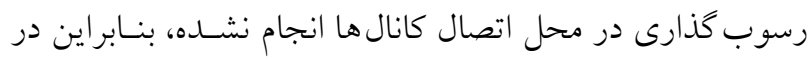

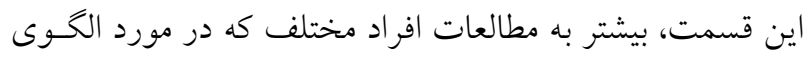
جريان در محل اتصال كانال ها انجام شده، برداخته خواهد شـد. بهلطور كلى مىتوان مطالعات انجامشده در زمينه الحــوى جريـان

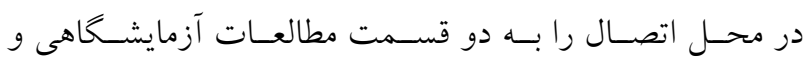
مطالعات عددى تقسيمبندى كرد.

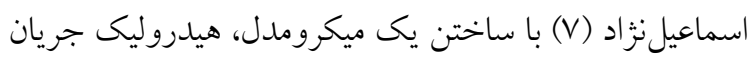
ورودى به آبخيرهاى سد انحرافى حميديسه را مـورد مطالعـه قـرار

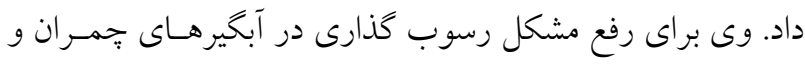

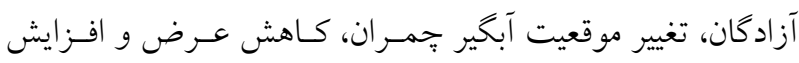

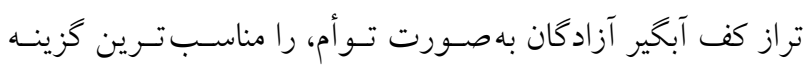

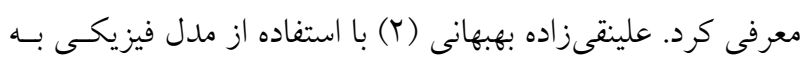

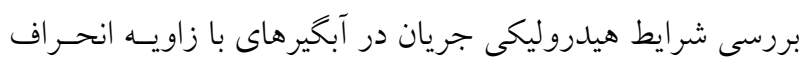

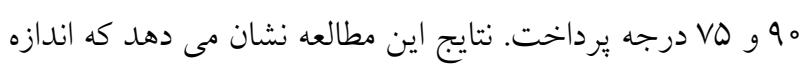

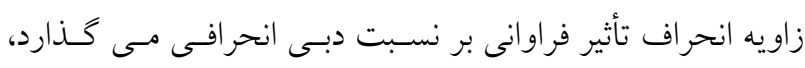

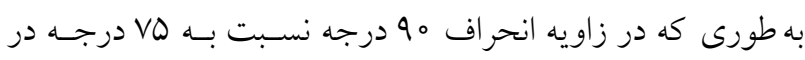

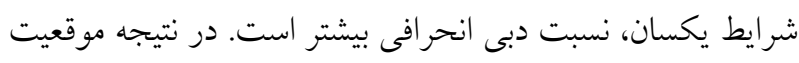

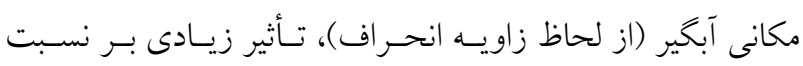

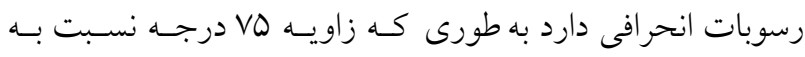

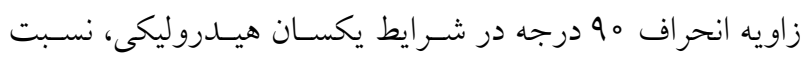


سهم رودخانه نيسان بيشتر از رودخانـه هوفـل اسـت. هـــف از

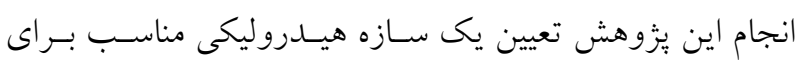

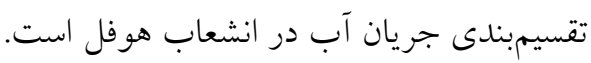

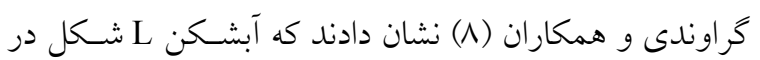

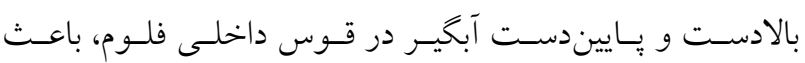

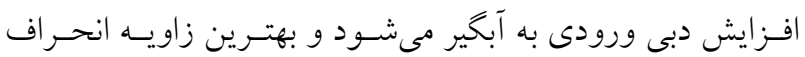
آبخير براى بيشترين دبى ورودى به آبخير، زاويه هو 9 درجه است.

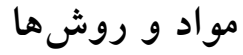
با توجه به اينكه يزوهش حاضـر، بروسى انشسعاب رودخانسه

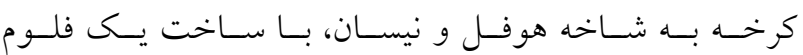

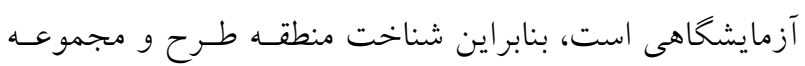

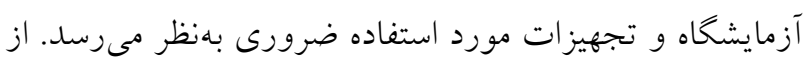

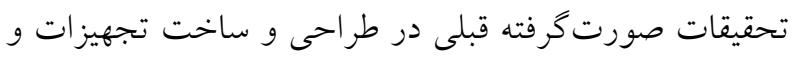
ابعاد آنها استفاده شده است. رودخانه كرخه يّ از اتصـال دو شـاخه سـيمره و كشـكان بهسمت جنوب شرقى جريـان يافتـه و يـس از دريافـت آب دو

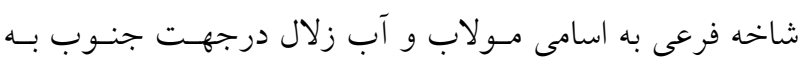

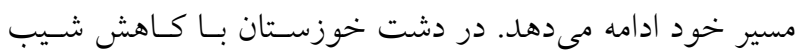
اراضى، شكل بستر رودخانه بهحالت مئاندر تغييـر شـكل يافتـه

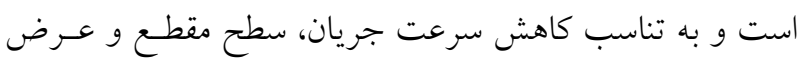

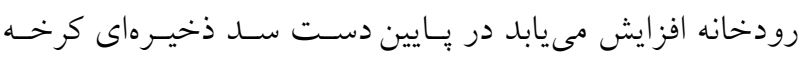

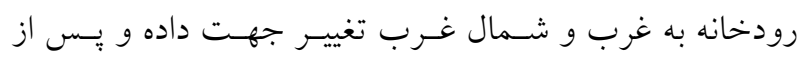

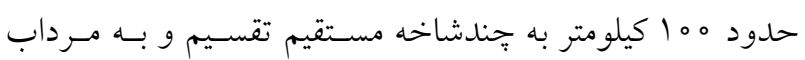

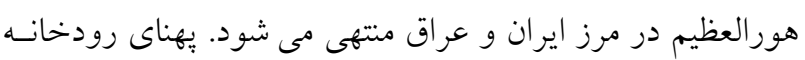

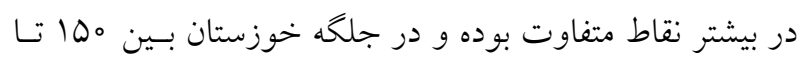

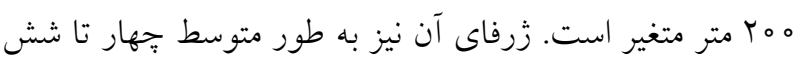
متر است (مو و rا).

\section{پارامترهاى فيزيوگر افى حوضه آبريز كرخه}

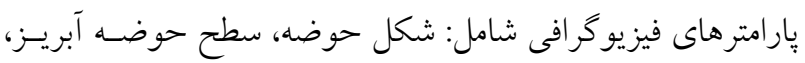

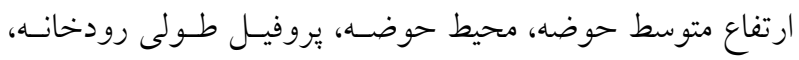

بود ثابت كردند كه جرخش هاى حلزونى ايجـاد شـده شَبيه دو

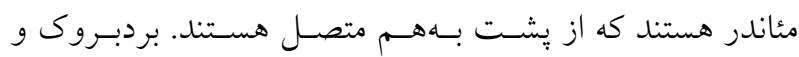

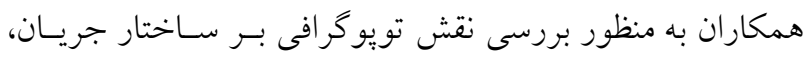

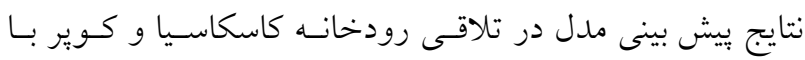
مورفولوزى واقعى و مورفولوزى مصنوعى را با هم مقايسه كرد.

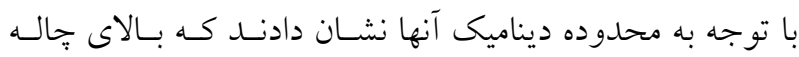

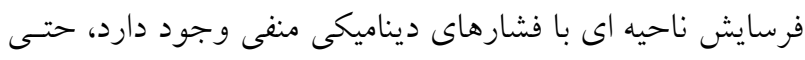

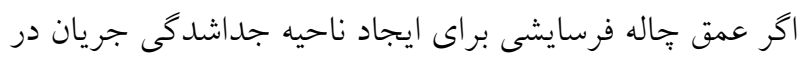

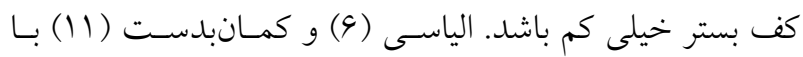

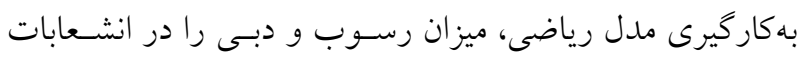

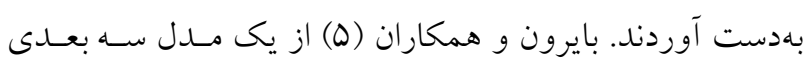
براى بررسى فرايند اختلاط جريان در پايين دست اتصال استفاده

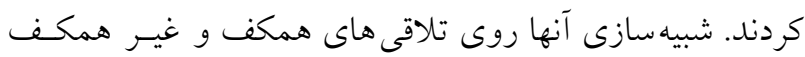

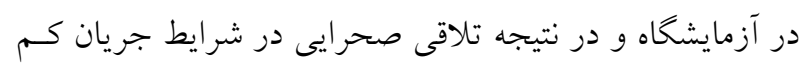

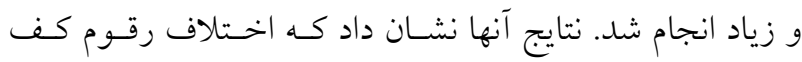
بستر تأثير جشمخيرى بر اختلاط جانبى جريان دارد. بـهـ كونسهاى

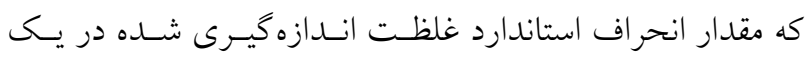

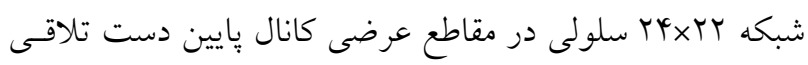

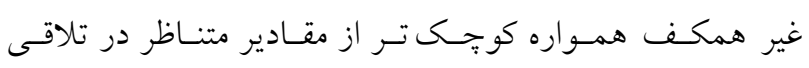

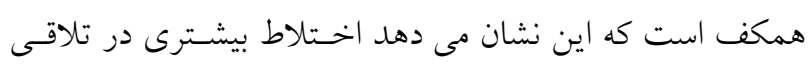

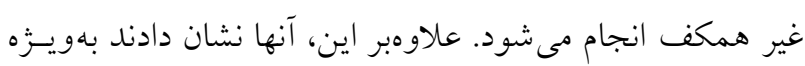

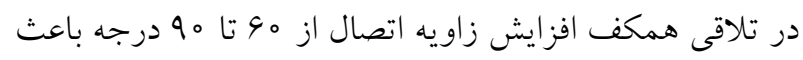
اختلاط سريعتر جريان مى نشود.

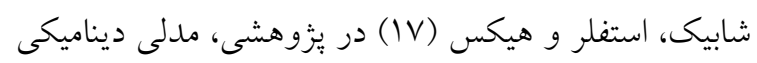
براى تجزيه وتحليل جريـان هـاى زيربحر انسى در محـل اتصـال

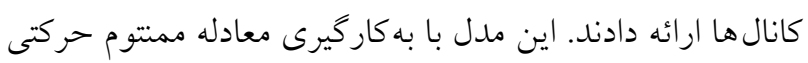

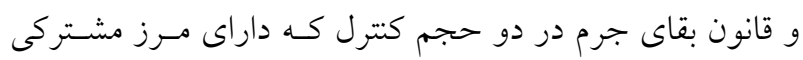

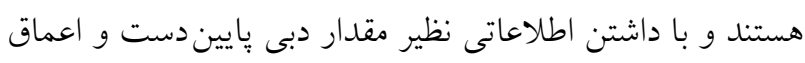
هاييندست، توانايى محاسبه و بــراورد اعمـاق بالادسـت را دارد.

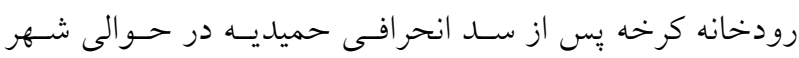

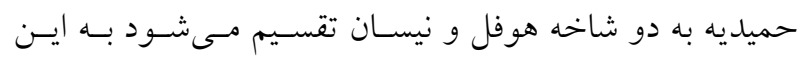
صورت كه در دبىهاى پايين بهعلت شيب زياد رودخانه نيسان، 
نشريه علوم آب و خاك (علوم و فنون كشاورزى و منابع طبيعى) / سال بيست و سه / ويزٔنامه سيل و فرسايش خاك / زمستان \هـا

جدول ا. بارامترهاى فيزيوكرافى حوضه آبريز كرخه

\begin{tabular}{|c|c|c|c|c|c|}
\hline $\begin{array}{c}\text { طول رودخانه } \\
\text { (km) }\end{array}$ & شيب متوسط & $\begin{array}{l}\text { ارتفاع متوسط } \text { حوضه (m) } \\
\text { (m) }\end{array}$ & مساحت حوضه & محيط حوضه & حوضه آبريز \\
\hline 194 & $\circ / 0$ & $9 \vee 9$ & TAMG & $r q 0$ & رودخانه ميمه تا ايستگاه بيات \\
\hline $\mid \mathrm{VI}$ & $\circ / 4$ & DQY & ryoo & r\&l & رودخانه دوبرج تا ايستگاه ربوط \\
\hline krv & 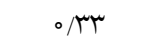 & $\mid Q Y \wedge$ & Frtra & ITTO & رودخانه كرخه تا ايستخاه پِاى پيل \\
\hline$q \mu$ &.$/ 19$ & lkto & YQYQS & 1910 & رودخانه كرخه تا ايستخاه حميديه \\
\hline VQ & $\circ / \circ \varphi^{t}$ & $\mid V / r$ & $010 \circ$ & ro。 & رودخانه كرخه از ايستخاه حميديه تا باتلاق هورالعظيم \\
\hline
\end{tabular}

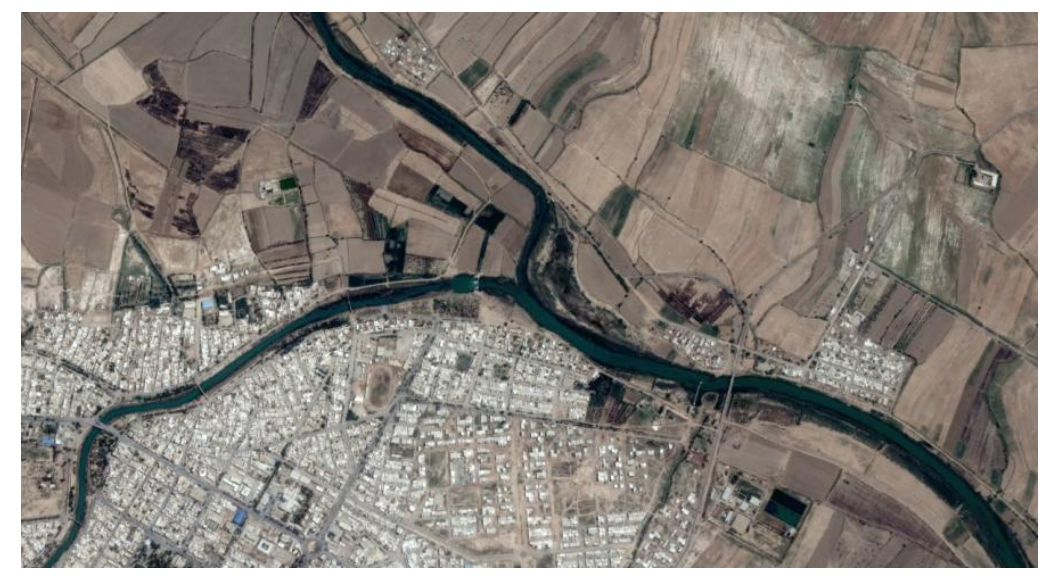

شكل 1. انشعاب رودخانه كرخه به شاخه هوفل و نيسان

رودخانه كرخه لازم است مؤثرترين آنها كه به صسورت هندسى و

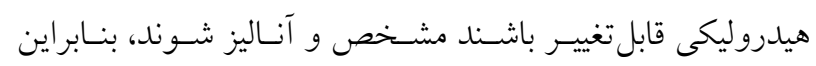

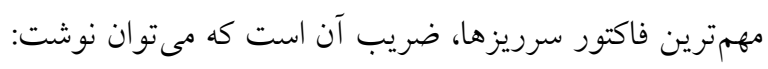
$\mathrm{Cd}=\mathrm{f}(\mathrm{g}, \mathrm{y}, \mathrm{V}, \mathrm{B}, \mathrm{h}, \mathrm{H}, \theta)$

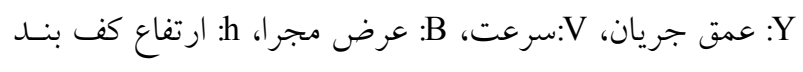

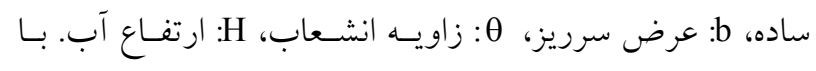

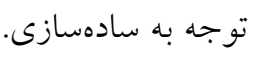

$$
c_{d}=f(f r, b / B, h / H, \theta)
$$

شكل (Y) نماى سرريز مستطيلى را نشان مىدهد.

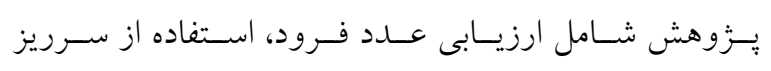

مستطيلى، تغيير در طول و ارتفاع سرريز است. متغيرها شامل:

$$
\text { 1. آزمايش با بينج دبى متفاوت (ينج متغير) }
$$

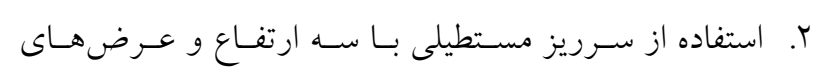

$$
\text { متفاوت (شش متغير) }
$$

شيب متوسط حوضه وشيب رودخانه اسـت. يارامترهـاى زيــر بــا

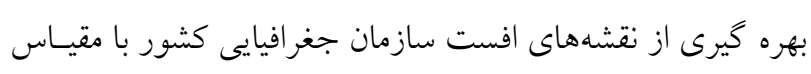

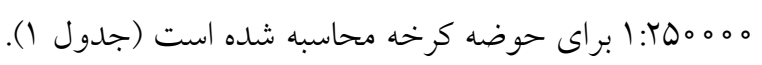

\section{آبدهى رودخانه كرخه در ايستخاه حميديه}

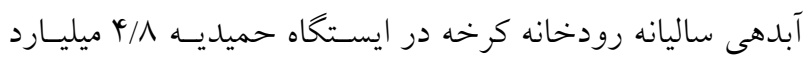

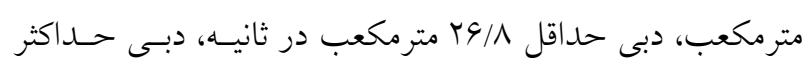

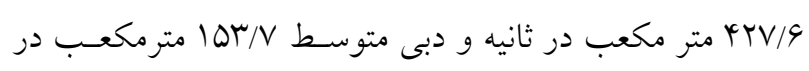

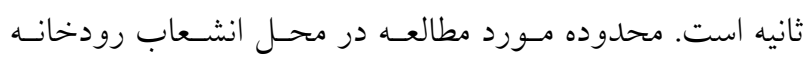
كرخها به شاخه هوفل و نيسان است (شكل (1).

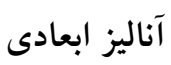
مطالعه بهصورت مدلسازى آزمايشگاهى انجام مى گيرد كه قبل از

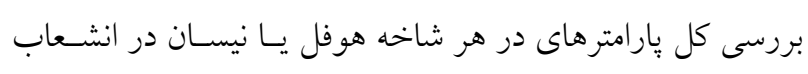



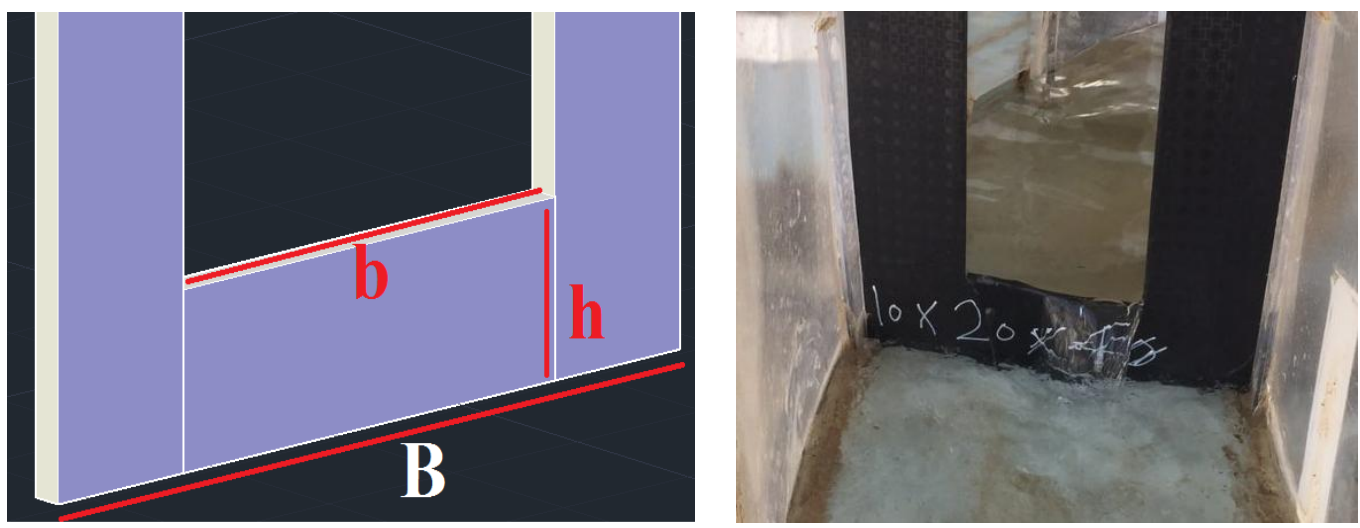

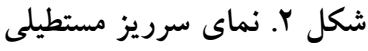

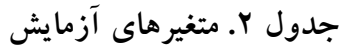

\begin{tabular}{|c|c|c|}
\hline $\mathrm{Fr}$ & سرريز مستطيلى با ابعاد متفاوت & زاويه انشعاب \\
\hline ه دبى & 4 & $r$ \\
\hline
\end{tabular}

جدول r. مشخصات و ابعاد موانع

\begin{tabular}{|c|c|c|c|c|c|c|c|c|}
\hline $\mathrm{b} / \mathrm{B}$ & $\mathrm{h} / \mathrm{H}$ & $\mathrm{h} / \mathrm{b}$ & $\mathrm{b}$ & $\mathrm{H}$ & B & $\mathrm{h}$ & نماى سرريز & شماره سرريز \\
\hline$\circ / 4$ & ०/० & $\circ / 0$ & $r_{0}$ & & & 1 & & 1 \\
\hline$\circ / 4$ &.$/ 1$ & $\circ / V Q$ & ro & & & $\mu$ & & r \\
\hline $0 / 9$ & & $\circ / 0$ & r。 & $\mu_{0}$ & Q. & & & r \\
\hline$\circ / 0$ & & $\circ / \wedge$ & ro & & & & b & q \\
\hline $\begin{array}{l}\circ / V \\
\circ / 9\end{array}$ & $\circ / \mathrm{V}$ & $\begin{array}{l}0 / O V \\
0 / 4 Y\end{array}$ & ro & & & $\Delta$ & h $\quad$ B & $\begin{array}{l}0 \\
9\end{array}$ \\
\hline
\end{tabular}

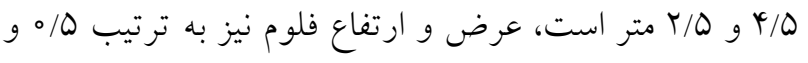
19/ه متر اسـت. مسير ورودى مسـتقيم (بـراى ايجـاد جريـان

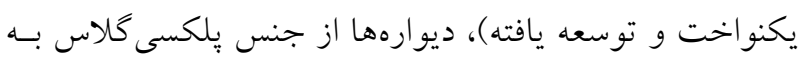

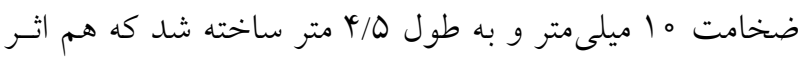

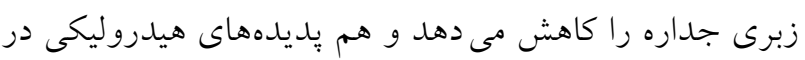
محفظه قابل رؤيت هستند، مسير خروجى نيز مستقيم، ديـواره

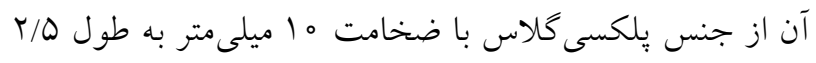

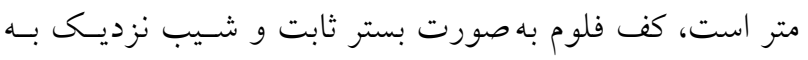

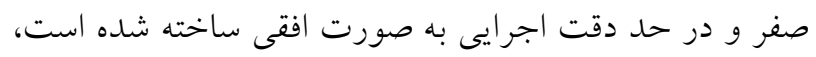

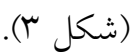
بعد از مخزن فلوم، يك دريجهـه كشـويى بـــاى تنظسيم دبـى r. ز زاويه انشعاب مبا و ه9 درجه (دو متغير)

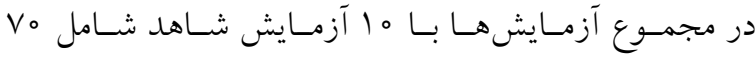

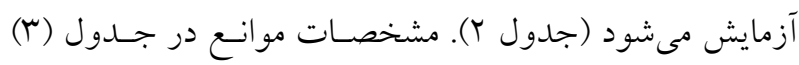
آمده است.

مشخصات فلوم ساختهده و نحوه ساخت آن

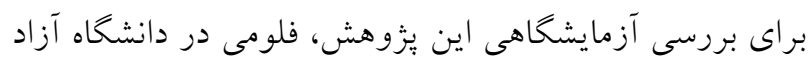

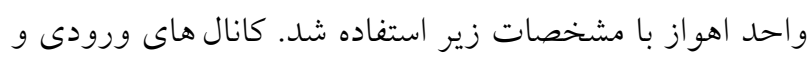

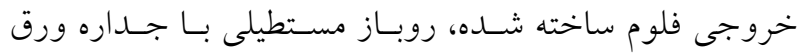

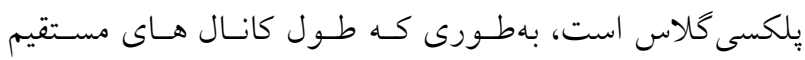

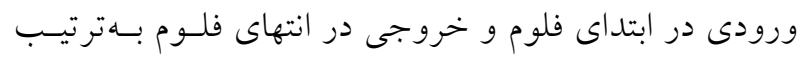


نشريه علوم آب و خاك (علوم و فنون كشاورزى و منابع طبيعى) / سال بيست و سه / ويزُهنامه سيل و فرسايش خاك / زمستان \هـ|
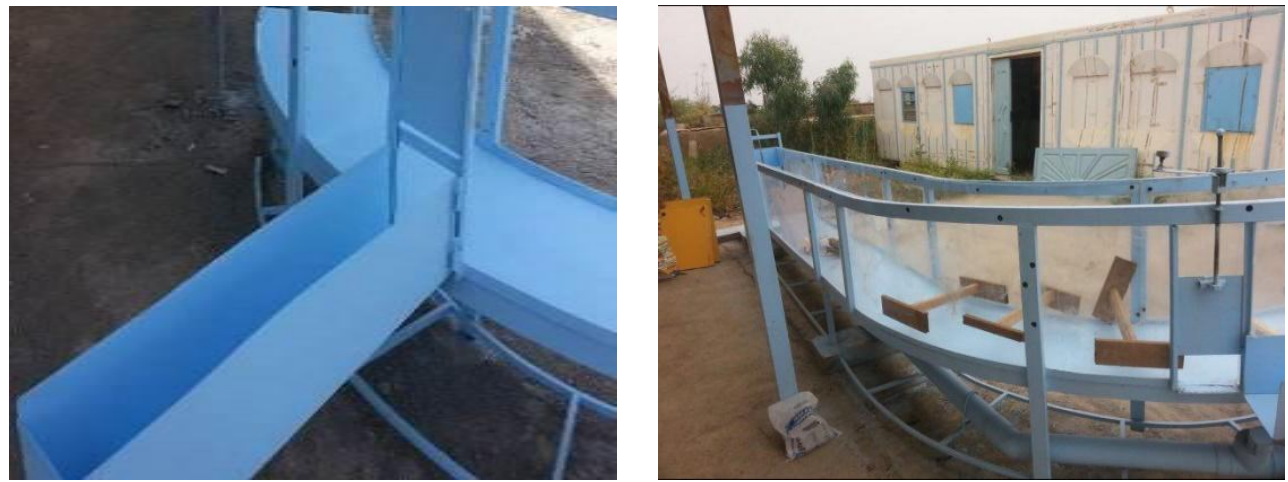

شكل r. نمايى از فلوم و محل انشعاب
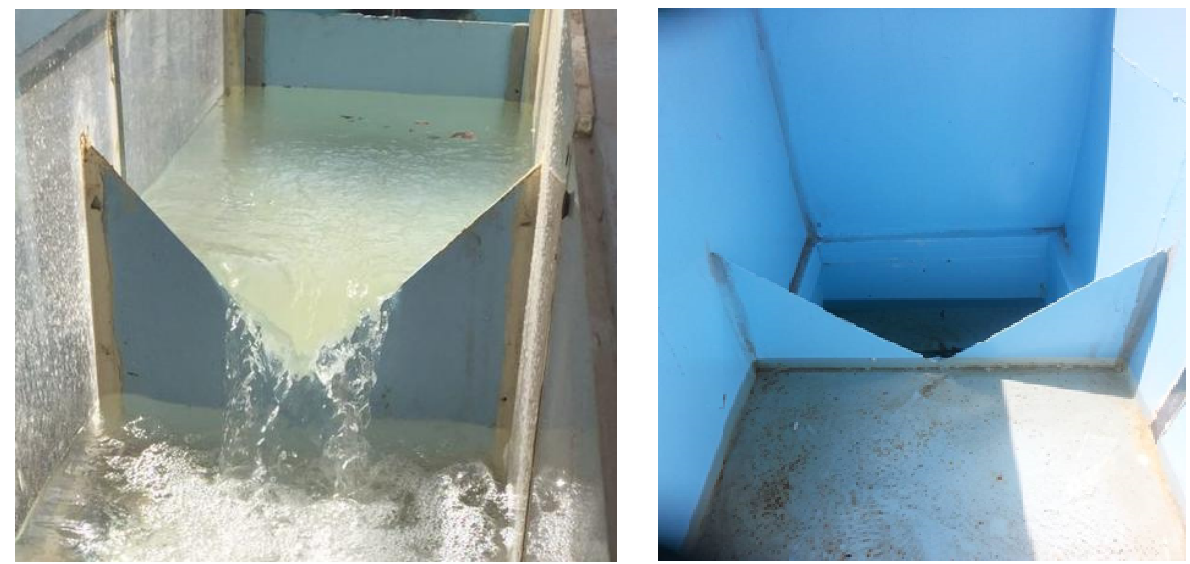

شكل †. سرريزهاى ورودى و خروجى مثلثى با رأس ه9 درجه در ابتدا و انتهاى فلوم

در انشعاب يرداخته شد كه بهمنظور تحقق اين هدف شش عـدد سرريز (شكل 9) با ارتفاع و عرض متفاوت ساخته شد.

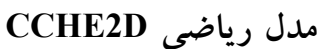

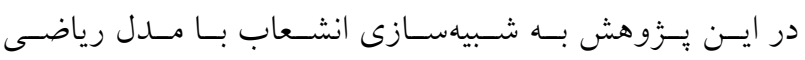
نCHE2D

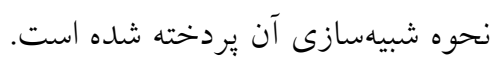
مدل CCHE2D در سال 1997 در مركز بين المللى محاسـبات

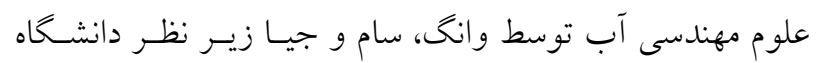

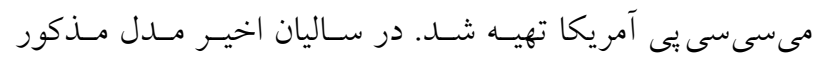

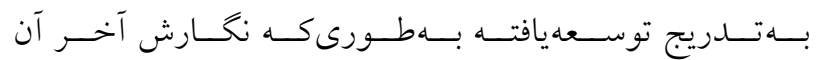
(CCHE2D 3.2) و رسوب برخوردار است. كدهاى اين برنامه با استفاده از زبـان

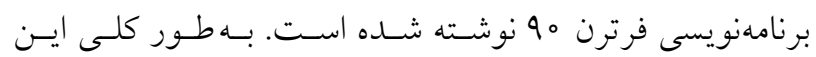

ورودى به فلوم و يكى سرريز مثلثى ه9 درجه براى اندازه كيــى دبى ورودى با فيلتر تورى و يوشال براى كرفتن تلاطم جريان و

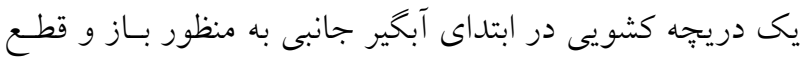

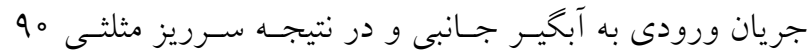
درجه در انتهاى فلوم، براى اندازه گيرى دبى خروجى انسي از فلوم، از

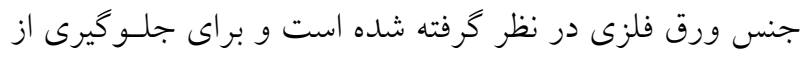

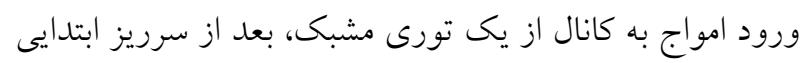
استفاده شده است (شكل أل).

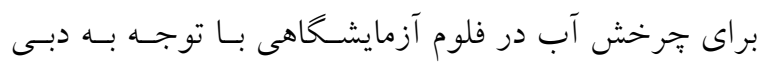

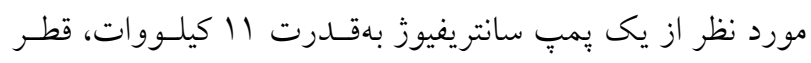

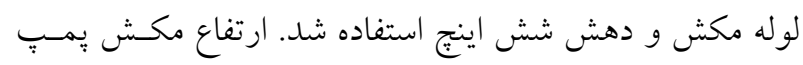

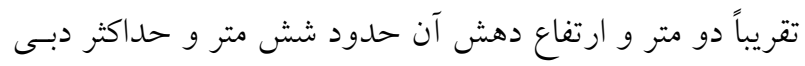

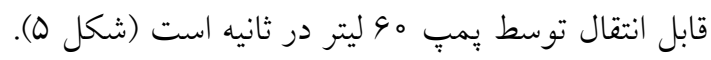

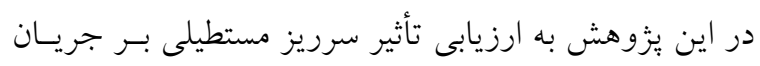




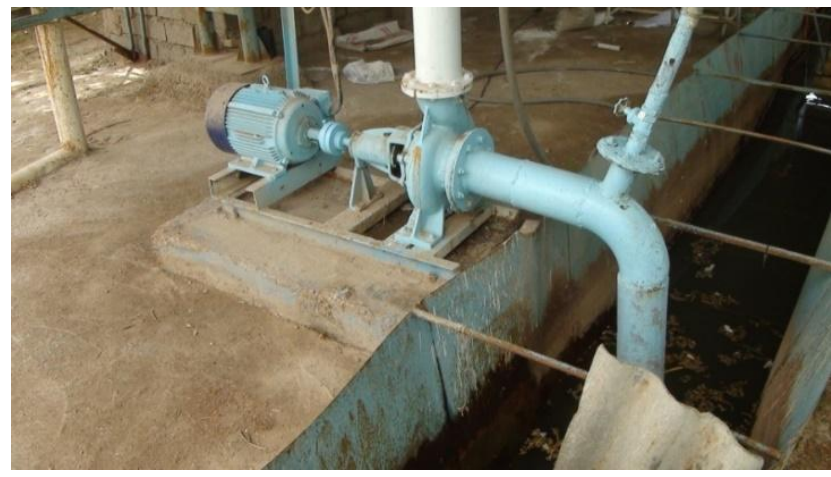

شكل ه. بمبٍ سانتريفيوز
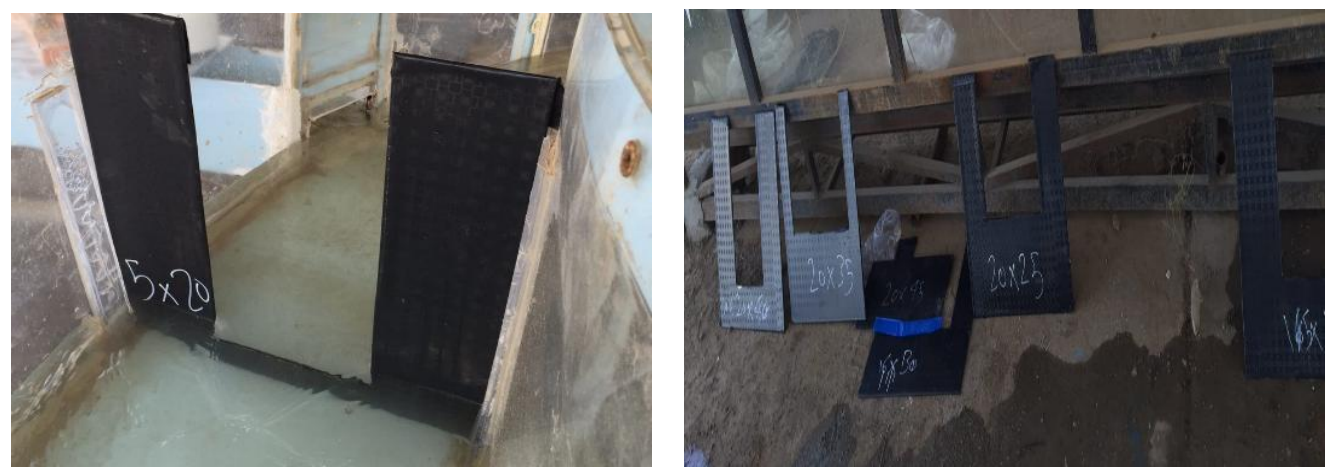

شكل 9. سر ريزهاى ساختهشده

برده و حل پيايدارى ارائه مى كند. ايسن معسادلات بـهروش المـان

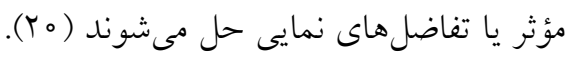

تهيه Mesh بر اساس ديتابيس فراهم شده از دادههاى تويوگر افى

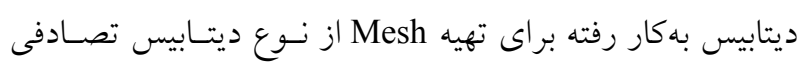

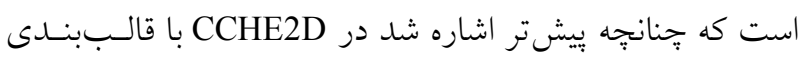

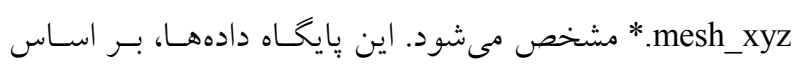

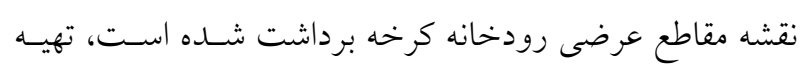
شد كه در شكل (V) نشان داده شده است.

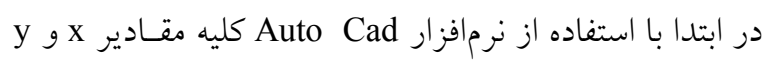

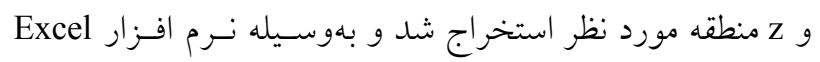

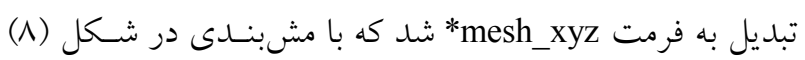
نشان داده شده است. دادههاى جريان شامل شرايط اوليه جريان، شـرايط مـرزى و و دان

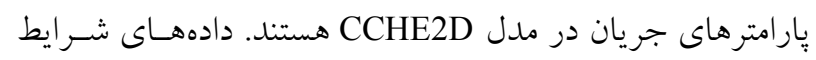

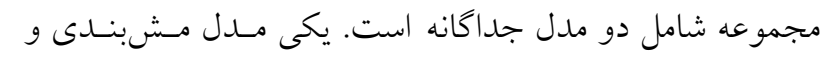
ديخرى مدلCCHE2D-GUI. مدل مشبندى بـا ايجـاد قابليـت

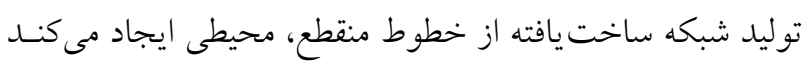

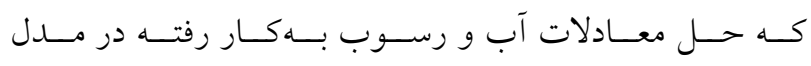
ار بر اساس روش عددى المان محدود ممكـن بـ CCHE2D-GUI

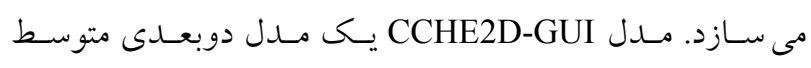
عمقى است كه شرايط جريان در اين مدل به صورت غيرماندكار

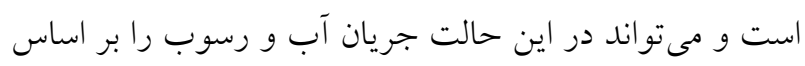

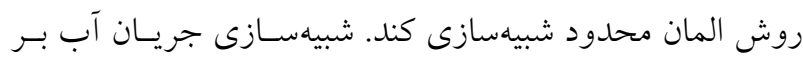

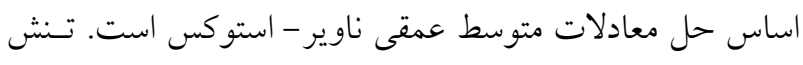

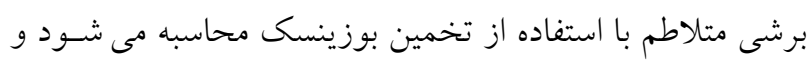

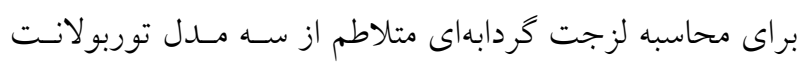

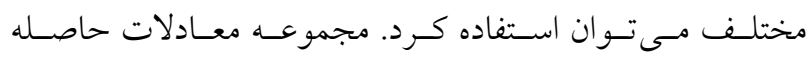

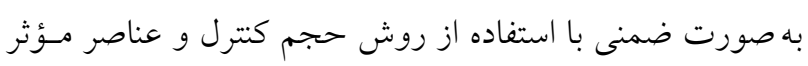

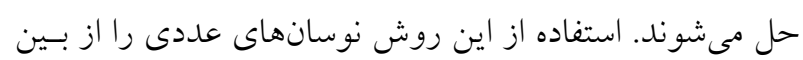


Initial Bed Elevation $(\mathrm{m})$

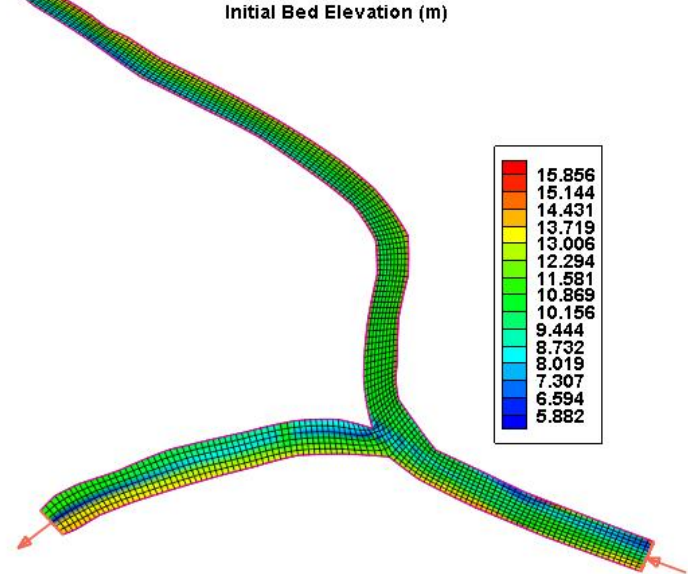

شكل V. شبكه mesh رودخانه كرخه با قالب ربندى geo.

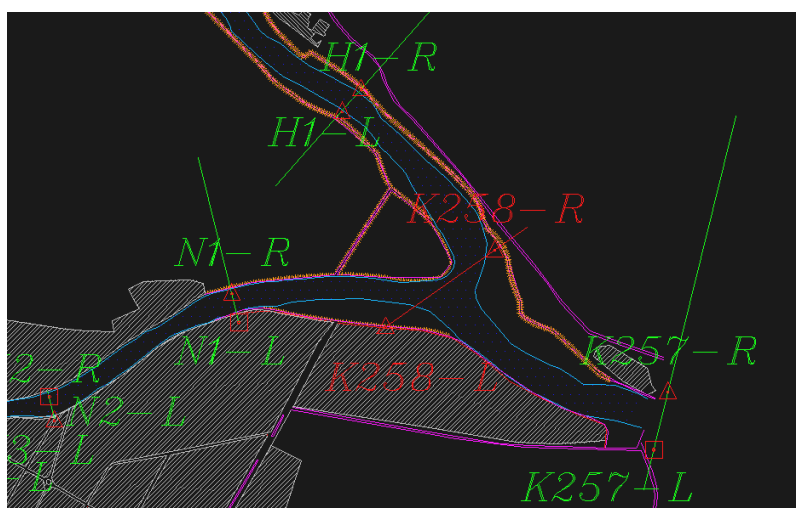

Auto Cad شكل ^^. خطوط هم تراز در نرمافزار

Parabolic Eddy Viscosity ،Mixing Length Model مس شـود Model بهدست آمده، مقدار ارتفاع آب در رودخانه در نرمافزار محاسبـه

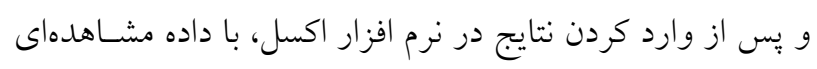

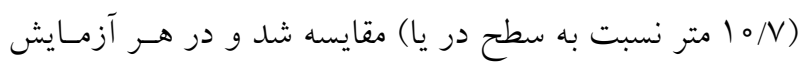
ميزان خطا محاسبه شد. در ابتدا با صحيح و خطـا كـردن زمـان

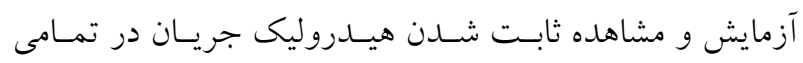

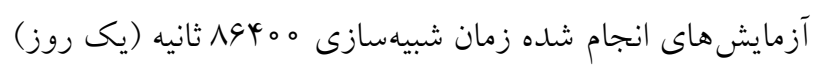

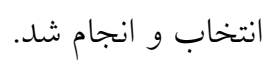

\section{نتايج}

هدف از اجراى مدل، بررسى نحوه تقسيم دبى در شاخه اسـت. با مطالعه رزيم هيـدروليكى جريـان بـراى دبسىهـاى حسداقل و
اوليه جريان شامل رقوم بستر اوليه، تراز سطح آب اوليه و زبرى اوليه بستر است. رقوم اوليه بستر همجنهان كه بيشتر كفته شد از طريق درونيـابى mesh بـر اسـاس تويـوخر افى اوليـه رودخانـه تعريف شده است. در نتيجه تراز اوليه سطح آب متناسب با اشل اندازه كيرى شده در رودخانه تعيين شده اسـت. شـرايط مـرزى جريان شامل جريان ورودى و ارتفاع آب در خروجى است كـه. مقادير دبى و اشل به صورت متوسط ماهانه در نظر كرفتـه شـد. براى كاليبره كـــدن مـــل، آزمـايش هــا بـا اسـتفاده از دادههـاى مشاهدهاى و در حالتهاى مختلف ضريب زبـرى و مــل هـاى آشفتكى انجام شد. جزئيات آزمايشها بهشرح زير است:

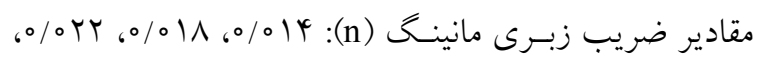
$.0 / 0 r^{\circ}, 0 / 049$ مدلهاى مهم و معمول آشـفتخى كـه در ايسن نـرم افـزار اسـتفاده 


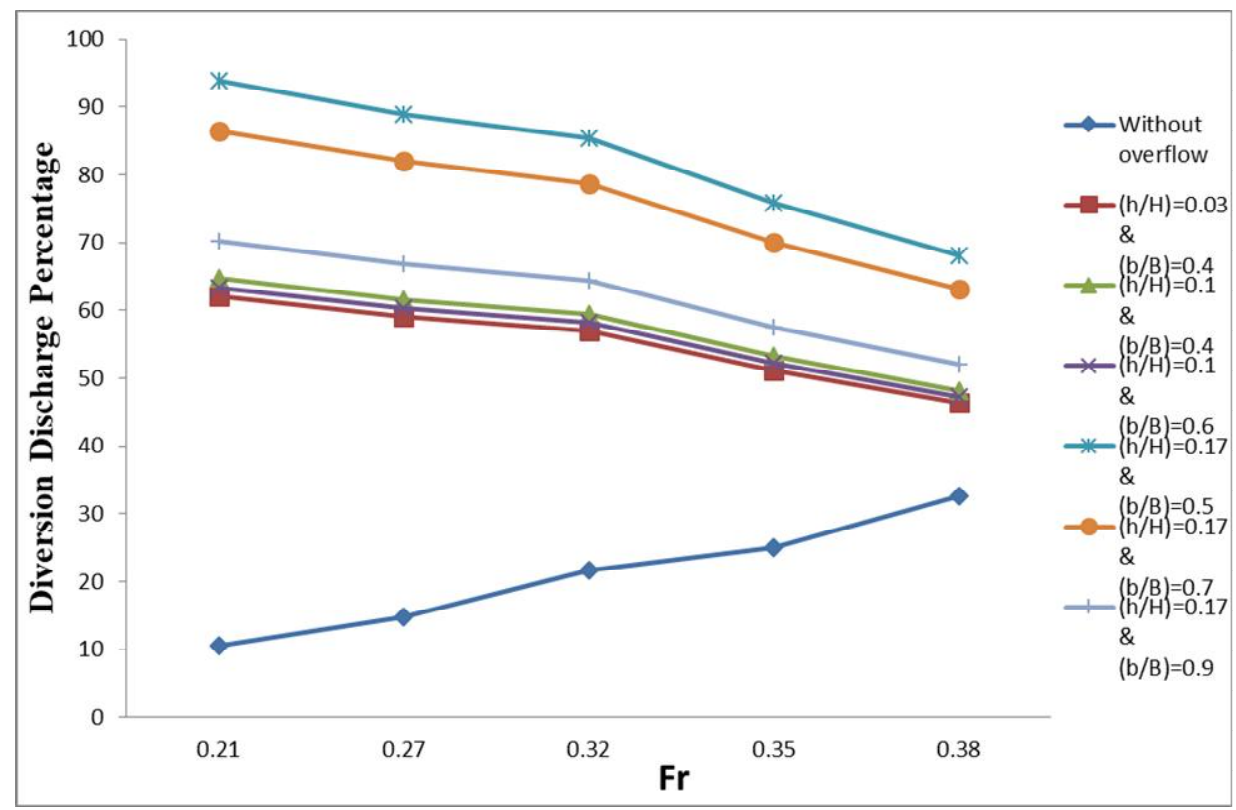

شكل 9.

بررسى نتايج درصد دبى انحر افى بـا تغييـر در ارتفـاع و عـرض سرريز مستطيلى پيرداخته شده است. با توجه به نمودار شكل (9) مىتوان بهخوبى مشـاهده كـرد با نصب سرريز مستطيلى در شاخه نيسان، رزيم جريـان عـوض شده و عمده جريان را بهسمت شاخه هوفل متمايل كرده اسـت. از نتايج مىتوان فهميد با افزايش ارتفاع سرريز بهدليـل افـزايش ارتفاع سطح آب، باعث افزايش درصد دبى انحر افـى بـه شـاخه هوفل شده است. در نتيجه با افزايش عرض سرريز بهدليـل كـم شدن ارتفاع سطح آب، درصد دبسى انحر افـى بـه شـاخه هوفـل

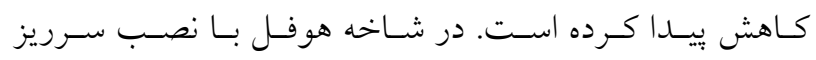
مستطيلى با ابعاد مختلف به طور متوسط حداقل ب/ بر و حــداكثر ه/ ا9 درصد افزايش دبى را شاهد هستيم.

بررسى اثر تأثير زاويه انشعاب بر درصد تقسيم دبى در شاخهها

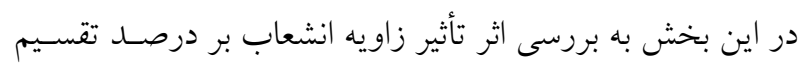
دبى در شاخهها برداخته شده است. بـا توجـهـ بـه نمـودار شـكل

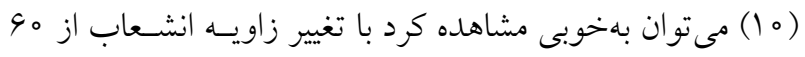
به هب درجه در اين مدل آزمايشـخاهى سـاخته شــده از انشـعاب هوفل و نيسـان در هـر دو حالـت شـاهد و در نتيجـهـ بـا سـرريز

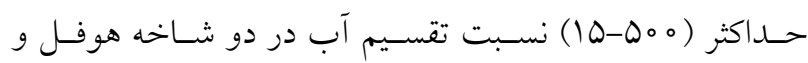
نيسان تعيين شد. (در دبىهاى يايين سـهم بيشـترى از دبسى بـه شاخه نيسان اختصاص مىيابد اما بعد از دبى هم م مترمكعب بر ثانيه بهدليل عـريض بــودن دهانـه ورودى شـاخه هوفـل رزيسم جريان تغيير مى كند) و ســس بــا اجـر اى مــل، سـازه كنترلى سرريز طراحى شد، به گونهاى كه نسبت دبى بـه دلخـواه مــنظر تأمين شود. به اين ترتيب نتايج در ينج بخش تقسيم مىشوند: ا. اثر تغيير در ارتفــاع و عـرض سـرريز مسـتطيلى بـر درصــ تقسيم دبى در شاخهها

r. اثر تأثير زاويه انشعاب بر درصد تقسيم دبى در شاخهها ז. اثر عدد فرود بر درصد تقسيم دبى در شاخهها

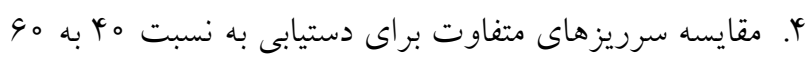
درصد دبى انحر افى به شاخه هوفل

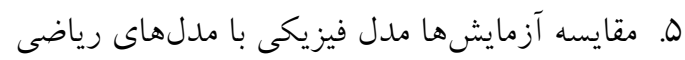

\section{بررسى اثر تغيير در ارتفــاع و عــرض سـرريز مسـتطيلى بـر درصد تقسيم دبى در شاخهها}

با انجام آزمايش ها، دادههاى لازم براى تحليل نتايج برداشت شد كه در قالب نمودارهايى در ادامه نشان داده مى شود. در ادامه بـهـ 
نشريه علوم آب و خاك (علوم و فنون كشاورزى و منابع طبيعى) / سال بيست و سه / ويزُهنامه سيل و فرسايش خاك / زمستان \هـا

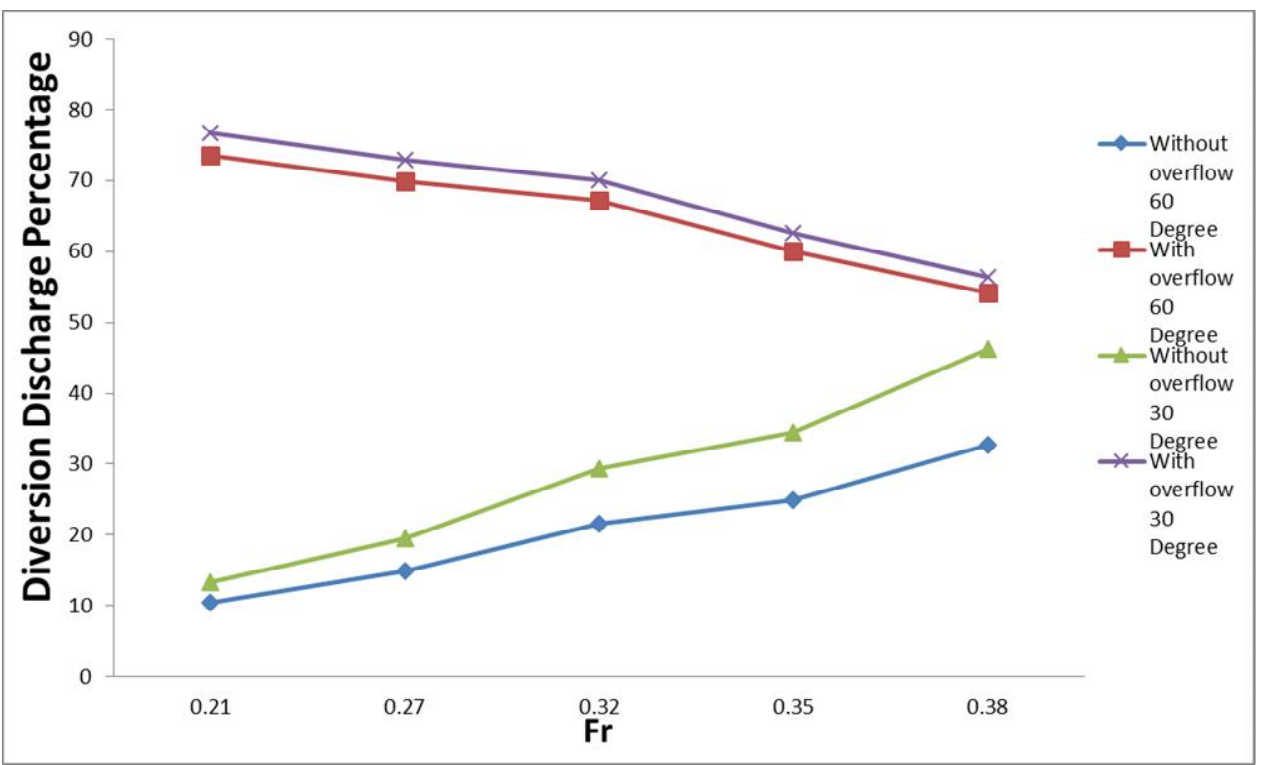

شكل • ا. نمودار درصد دبى انحرافى به شاخه هوفل در دو زاويه انشعاب

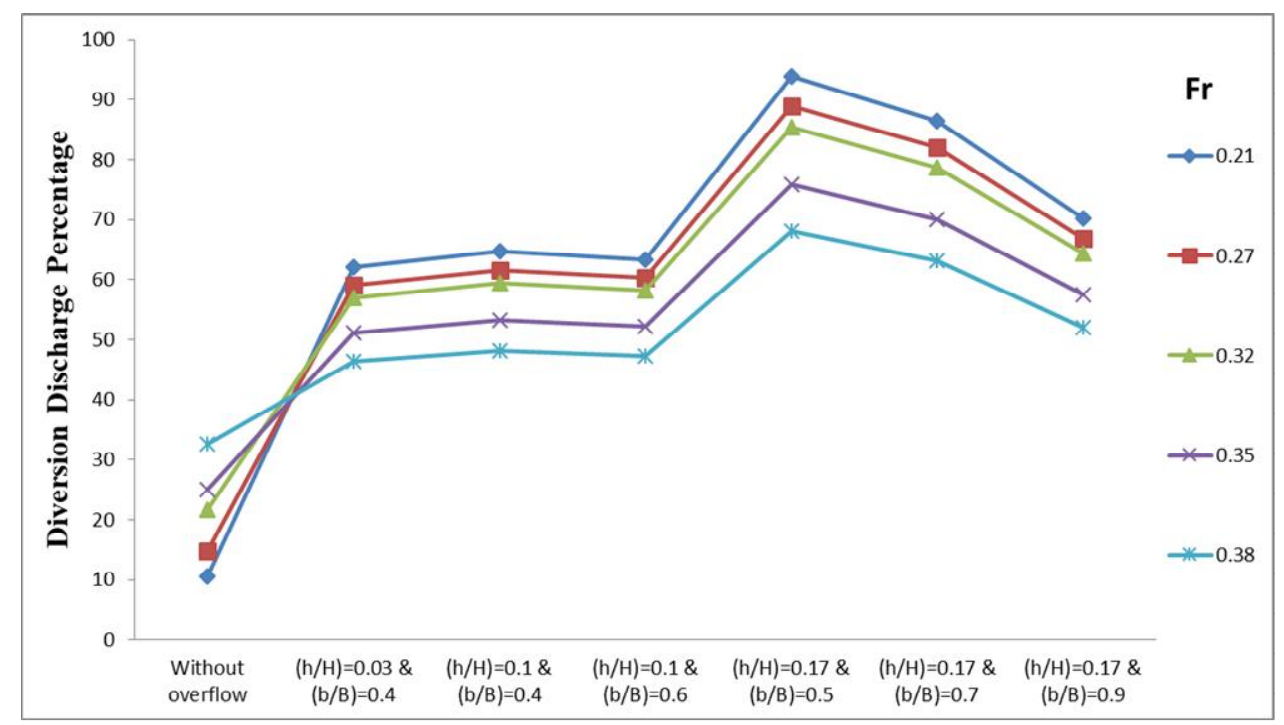

شكل 11. نمودار تأثير عدد فرود بر درصد دبى انحرافى به شاخه هوفل

مى توان مشاهده كرد درصد دبى انحرافـى بـه شـاخه هوفـل بررسى اثر عدد فرود بر درصد تقسيم دبى در شاخهها افز ايش بيداكرده است. البته در حالت طبيعى و بلدون نصـب در اين بخش به بررسى اتـر عـدد فـرود بـر درصـد تقسيم دبسى در

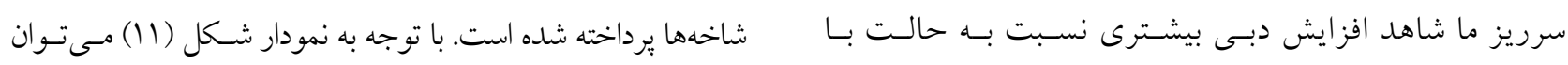

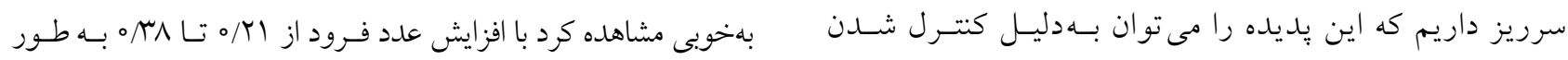
متوسط باعث كاهش درصد دبى انحرافى به اندازه س/9 درصـد شـده

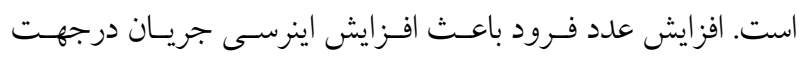
جريان توسط سرريز اعلام كرد. به طور متوسط در حالـت بـا مستقيم شده و باعث كاهش انحراف آب به انشعاب مىشود. سرريز T/A درصد و بلدون سرريز V/V درصد افزايش درصــ دبى انحرافى داشته است. 
جدول f. درصد دبى انحرافى به هر شاخه با سرريزهاى متفاوت

\begin{tabular}{|c|c|c|c|c|c|c|}
\hline$\circ / \uparrow \wedge$ & $\circ / \mu$ & $0 / \mu r$ & $0 / Y V$ & $0 / T_{1}$ & $\mathrm{Fr}$ & \\
\hline$k q / 4$ & $01 / T$ & $\Delta V$ & $09 / T$ & $G Y / 1$ & هوفل & $(\mathrm{h} / \mathrm{H})=0.03$ \\
\hline Or/G & $\uparrow \wedge / q$ & pr & $4 \circ / 9$ & $r V / q$ & نيسان & $(b / B)=0.4$ \\
\hline$Y \wedge / Y$ & $\Delta r / T$ & $09 / 4$ & $91 / 9$ & SY/V & هوفل & $(\mathrm{h} / \mathrm{H})=0 / 1$ \\
\hline DI/A & $49 / 1$ & $4 \circ / 9$ & $\mu_{\Lambda / \uparrow}$ & $r \Delta / r$ & نيسان & $(b / B)=o / 4$ \\
\hline $\mathcal{Y} V /$ & $\Delta T / T$ & $\Delta \Lambda / T$ & $90 / 4$ & $4 \pi / 4$ & هوفل & $(\mathrm{h} / \mathrm{H})=0 / 1$ \\
\hline$\Delta T / V$ & $\Psi V / \Lambda$ & $41 / \Lambda$ & $r q / 9$ & re/9 & نيسان & $(b / B)=0 / 9$ \\
\hline $9 / / 1$ & $\mathrm{VQ} / \mathrm{A}$ & $\Lambda Q / 4$ & 19 & $9 \pi / 1$ & هوفل & $(\mathrm{h} / \mathrm{H})=0 / \mathrm{IV}$ \\
\hline$r 1 / 9$ & $Y Y / T$ & $14 / 9$ & 11 & $9 / \pi$ & نيسان & $(b / B)=0 / \Delta$ \\
\hline$q \pi / 1$ & $V 0 / 1$ & $V \wedge / \Lambda$ & NT & $\wedge 9 / 4$ & هوفل & $(\mathrm{h} / \mathrm{H})=0 / \mathrm{IV}$ \\
\hline$r 4 / 9$ & $r 9 / 9$ & $r Y / r$ & 11 & $1 \pi / 9$ & نيسان & $(\mathrm{b} / \mathrm{B})=0 / \mathrm{V}$ \\
\hline$\Delta T / 1$ & $\Delta V / 9$ & $G 4 / 4$ & $99 / 9$ & $V \circ / \mu$ & هوفل & $(\mathrm{h} / \mathrm{H})=0 / \mathrm{IV}$ \\
\hline$r V / q$ & $K T / 4$ & $r \Delta / 9$ & T/1 & $r q / V$ & نيسان & $(b / B)=0 / 9$ \\
\hline
\end{tabular}

شد. جزئيات آزمايش بهشـرح زيــر اسـت: مقـادير ضـريب زبـرى

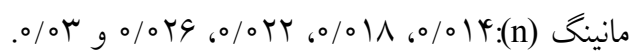
مدلهاى مهم و معمول آشفتكى كه در اين نرمافزار اسـتفاده مىشود، Mixing Length Model و Model آزمايش ها كاليبره كردن، كمترين خطا در آزمايش ها با استغاده از

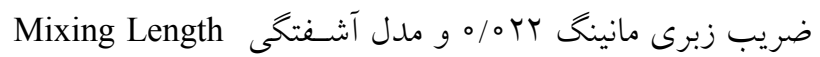

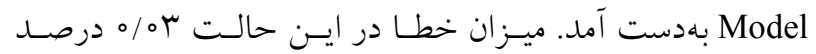
است. حال با استفاده از مقادير بهدست آمــده در فراينـــ كـاليبره

كردن، آزمايشهاى موردنظر را انجام مىدهيم (جدول ه). بـا شـبيهسـازى انشـعاب در مــدل رياضـى CCHE2D و استخراج نتايج از اين مدل به نتايج گرافيكى (شكل rا و ما) و نتايج عددى برداخته شد كه در ادامه نتـايج آزمـايشهـاى مـدل فيزيكى با مدل رياضى CCHE2D مقايسه شد. اين يـزّوهش بـــ تأثير استفاده از سرريزهاى مستطيلى در انشعابها انجام شد كـهـ در زير خلاصه نتايج آن آمده است:

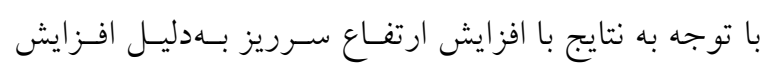

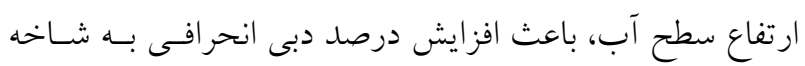

مقايسه سرريزهاى متفاوت براى دستيابى به نسبت م fo بـه درصد دبى انحرافى به شاخه هوفل در اين بخـش بـه مقايسـه سـرريزهاى متفـاوت بـراى دستيابى به نسبت ه4 به مو درصد دبى انحر افى به شاخه هوفل برداختسه

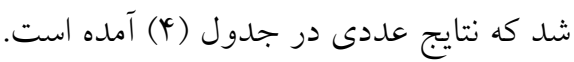
با توجه به جدول (r) مى توان مشاهده كرد با نصب سـرريز

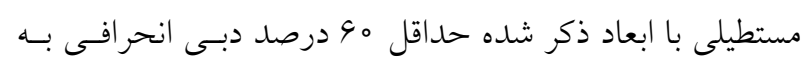

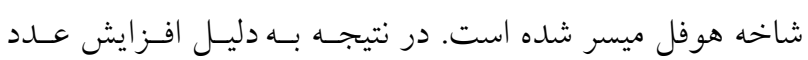
فرود باعث تغيير درصد دبى هاى انحرافى شده است و به همـين

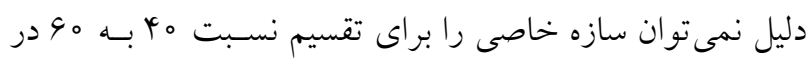
همه دبىها در نظر كرفت. اما بهطور متوسط نزديكتـرين سـازه بــهـ ايــن تقســيم درصــد را مـى تــوان ســرريز بـــا ابعـاد (h / H) = دانست / IV \& (b / B) = / V

مقايسه آزمايشهــاى مـدل فيزيكـى بــا مـدلهــــ رياضـى CCHE2D براى كاليبره كردن مدل، آزمايش ها با استفاده از دادههاى مشـاهدهاى و در حالتهاى مختلف ضريب زبرى و مدلهـاى آشـفتكى انجـام 
نشريه علوم آب و خاك (علوم و فنون كشاورزى و منابع طبيعى) / سال بيست و سه / ويزٔنامه سيل و فرسايش خاك / زمستان \هـ1

\begin{tabular}{|c|c|c|c|}
\hline \multicolumn{4}{|c|}{ جدول ه. نتايج آزمايشهاى كاليبراسيون } \\
\hline درصد خطا & ضريب زبرى (n) & 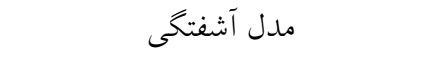 & 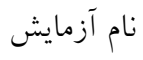 \\
\hline$-0 / \Gamma_{4}$ & & Parabolic Eddy Viscosity Model & سناريو 1 \\
\hline$-0 / T 9$ &.$/ 014$ & Mixing Length Model & 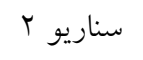 \\
\hline$-\circ / \mu$ & & K-Epsilon Model & سناريو r \\
\hline$-0 / Y r$ & & Parabolic Eddy Viscosity Model & سناريو ب \\
\hline$-0 / 1$ &.$/ 01 \wedge$ & Mixing Length Model & سناريو ه \\
\hline$-0 / 19$ & & K-Epsilon Model & سناريو 9 \\
\hline$-\circ / 1$ & & Parabolic Eddy Viscosity Model & 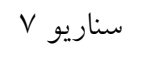 \\
\hline$\circ / \circ$ & \%OrT & Mixing Length Model & سناريو \\
\hline$-0 / 04$ & & K-Epsilon Model & سناريو 9 \\
\hline$\circ / 1$ & & Parabolic Eddy Viscosity Model & سناريو •1 \\
\hline $0 / r$ & \%०YG & Mixing Length Model & سناريو 11 \\
\hline $0 / 19$ & & K-Epsilon Model & سناريو r| \\
\hline $0 /$ TY & & Parabolic Eddy Viscosity Model & سناريو سا \\
\hline $0 / 49$ & $\circ / \circ$ & Mixing Length Model & سناريو \\
\hline$\circ / \pi$ & & K-Epsilon Model & سناريو 10 \\
\hline
\end{tabular}
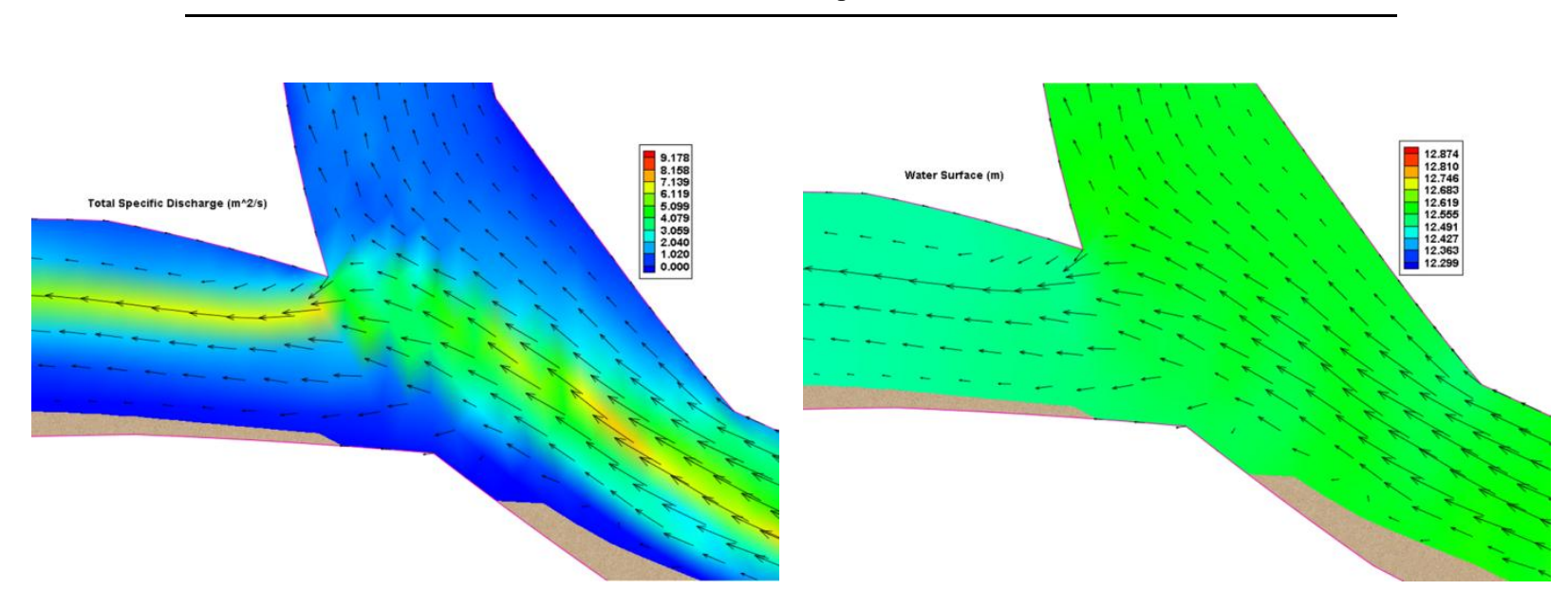

شكل r I. نتايج گر افيكى مدل رياضى در دبى ॰ ه مترمكعب بر ثانيه بدون سازهبند

شاهد و در نتيجه با سرريز مى توان مشـاهده كـرد درصـد دبسى

انحرافى به شاخه هوفل افزايش بيداكرده است. البته در با توجـهـ

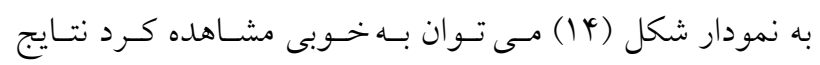

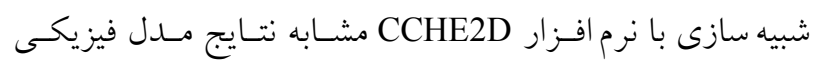

است، نتايج شبيهسازى با نرمافزار CCHE2D نشان مسىدهـــ بـا

افزايش عدد فرود درصد دبى انحرافـى بـهـ شـاخه هوفـل رونسد
هوفل شده است. در نتيجه با افزايش عرض سرريز بهدليـل كـم شدن ارتفاع سطح آب، درصد دبسى انحرافى بـه شـاخه هوفـل كاهش بيداكرده است. در شاخه هوفل با نصب سرريز مستطيلى

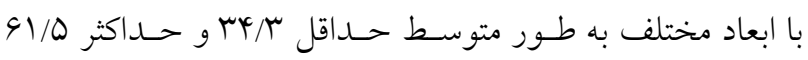
درصد افزايش دبى را شاهد هستيم.

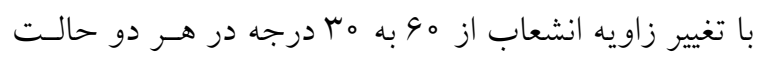




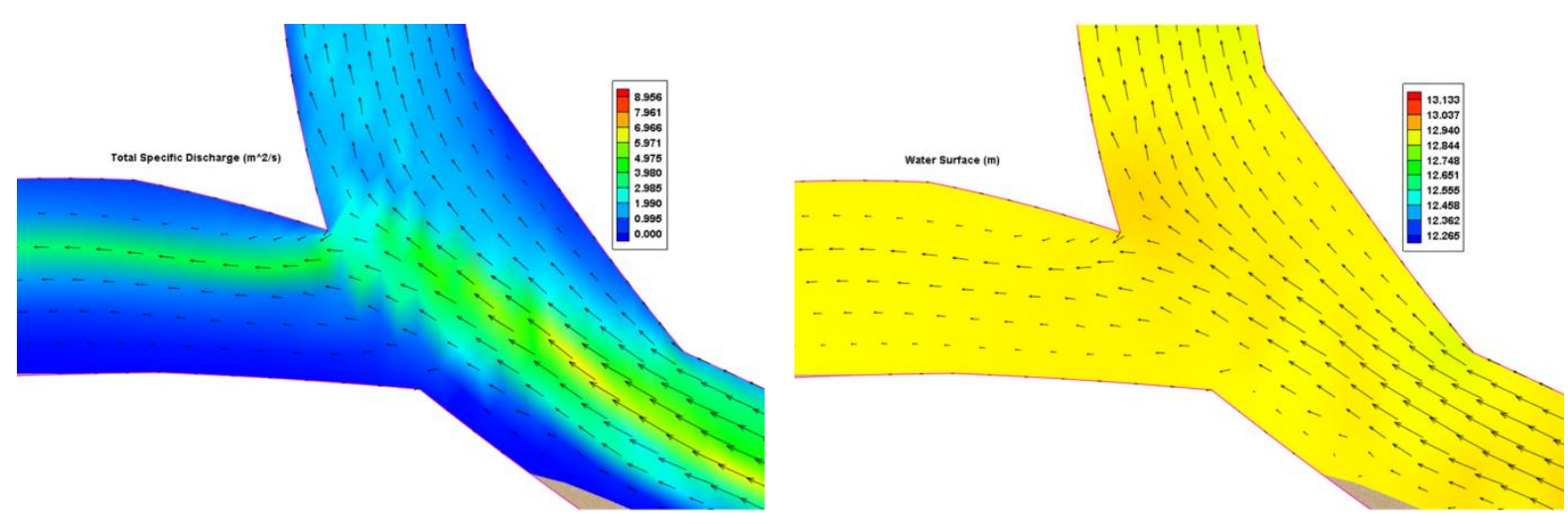

شكل سا. نتايج گر افيكى مدل رياضى در دبى همه مترمكعب بر ثانيه با سازهبند

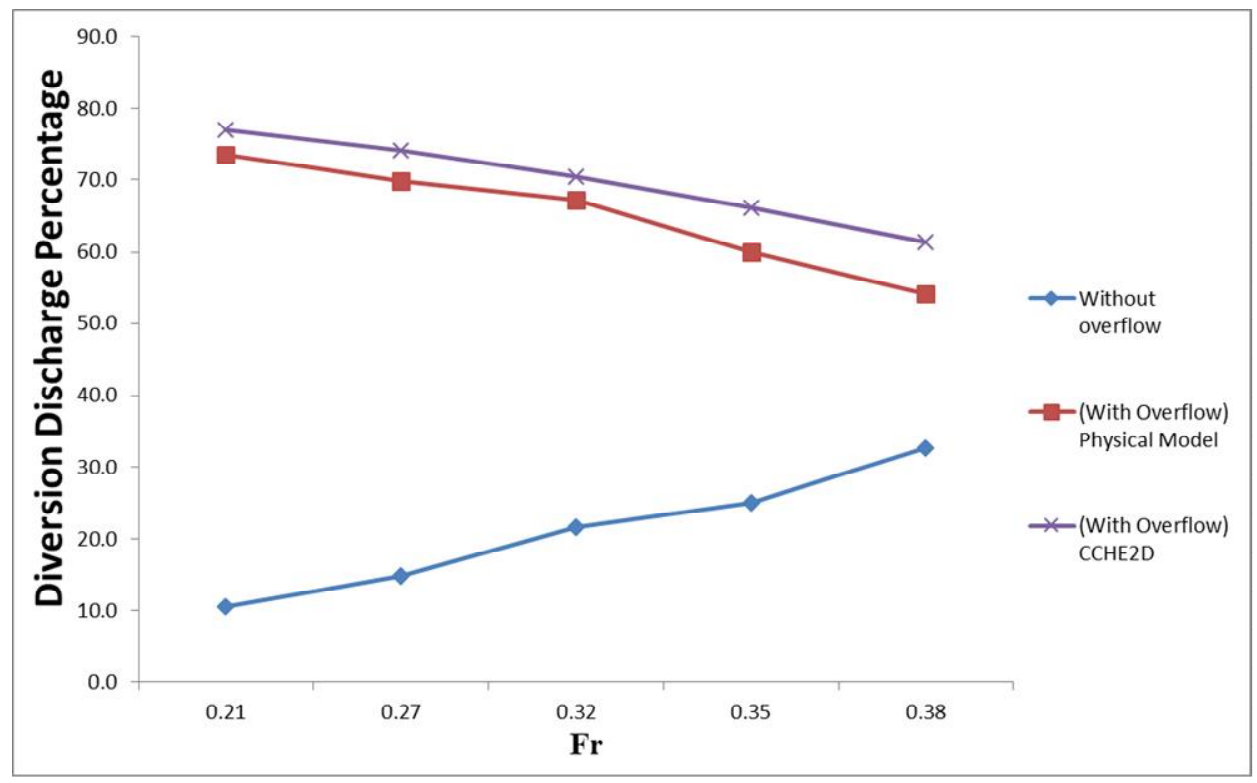

شكل \& 1ا. نمودار مقايسه نتايج مدل فيزيكى با مدل رياضى

$\mathrm{Q}=r r / r \frac{b}{\mathrm{~B}}-r V q / r \frac{\mathrm{h}}{\mathrm{H}}+r \Delta / \varphi$

(r) لزولى داشته كه بسيار مشابه و نزديك به نتايج آزمايش هـا مــل

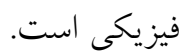

\section{نتيجه گيرى}

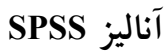

در رودخانههايى كه به دو شاخه تقسيم مىشـوند رزيـم جريـان همانطور كه از گر اف ها مشاهده مى شود مقادير تقسيم دبسى در شايد به كونهاى باشد كه كه دبسى لازم در شـاخه مسـنظر تقسيم

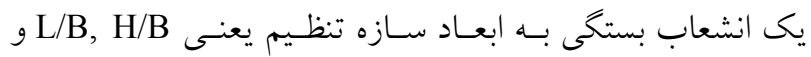

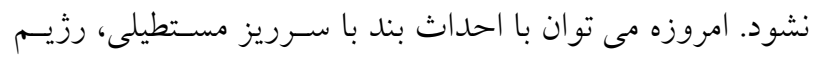

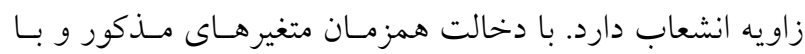
جريان را براى استفاده مورد نياز تغيير داد. از ايـن رو در حالـت فئس

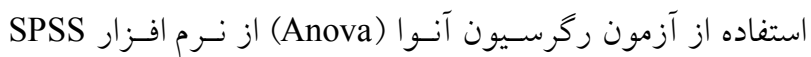

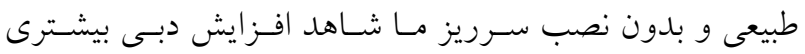

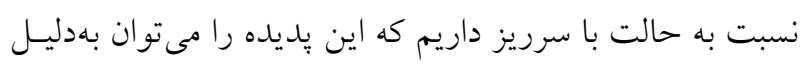

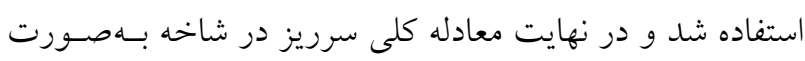

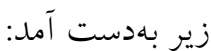


با نصب سرريز مستطيلى با ابعاد ذكر شده حداقل ه9 درصد

دبى انحرافى به شاخه هوفل ميسر شده است. در نتيجه بـهدليـل

افزايش عدد فرود باعث تغيير درصد دبسىهـاى انحرافى شــــ

است و به همين دليل نمى تـوان سـازه خاصسى را بـراى تقسـيم

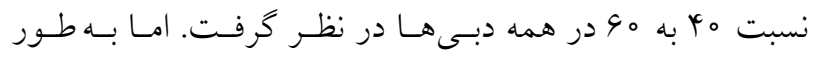

متوسط نزديكترين سازه به اين تقسيم درصد را مىتوان سرريز

با ابعاد h / /
حالت با سرريز Y/A درصد و بدون سرريز V/V درصـد افـزايش

درصد دبى انحرافى داشته است. با افزايش عدد فرود از آ/ تاء تا

^ץ/ه باهطور متوسط باعث كاهش درصد دبى انحرافى بــانــازه

19/1 درصد شده است.

نتايج شبيه سازى با نرم افـزار CCHE2D مشـابه نتـايج مــدل

فيزيكى است، نتايج شبيه سـازى بـا نـرمافـزار CCHE2D نشـان

مىدهد با افزايش عدد فرود درصد دبى انحرافى به شاخه هوفل

روند نزولى داشته كه بسيار مشابه و نزديك به نتايج آزمايش هـا

منابع مورد استفاده

1. Afshin, Y. 1994. Rivers of Iran. Jamab Consulting Engineers Company. Iran.

2. Aliqizadeh Behbahani, H. 2003. Investigation of Hydraulic Flow Conditions in Ponds with 90 and 75 Degree Angle Using Model, Physics, MSc. Thesis, Shahid Chamran University, Ahvaz. (In Farsi).

3. Borghei, S. M., S. M. Sokhiefar and A. Daemi. 2002. Experimental investigation of channel binding. In: Proceedings of the $6^{\text {th }}$ International River Seminar, Ahvaz.

4. Borghei, S. M, A. S., Behrangi and A. Daemi. 2002. Investigation of the separation zone at the flow plug connection using a laboratory model. In: Proceedings of the $6^{\text {th }}$ International River Seminar, Ahvaz. (In Farsi).

5. Bradbrook, K. F., S. N. Lane, K. S. Richards, P. M. Biron and A. G. Roy. 2000b. Numerical simulation of threedimensional, time-averaged flow structure at river channel confluences. Water Resources Research 36(9): 27312746.

6. Elyasi, M. and A. A. Kamanbedast. 2014. The effect of angle of intakes on diversion sediments in river bend with CCHE2D model, Advance in Environmental Biology 8(22): 180-186.

7. Esmail Nejad, M. P. 2002. Laboratory investigation of hydraulic inlet flow to hamidie diversion dam ponds using micromodel, MSc. Thesis, Shahid Chamran University, Ahwaz. (In Farsi).

8. Gravandi, E., A. A. Kamanbedast, A. L. Masjedi, M. Heidarnejad and A. Bordbar. 2018. Laboratory investigation of the impact of armor dike simple and 1-shaped in upstream and downstream intake of the hydraulic flow river and intake flow rate, Journal of Water and Soil Science 22(3): 55-70.(In Farsi).

9. Hosseini, M. and J. Abrishami. 2002. Hydraulics of Open Channels, Imam Reza International University. (In Farsi).

10. Kamanbedast, A. A. 2010. CCHE2D Software Manual, Islamic Azad University, Ahvaz Branch. (In Farsi).

11. Kamanbedast, A. A., R. Nasrollahpour and M. Mashal. 2013. Estimation of Sediment transport in rivers using CCHE2D model (case study: karkheh river), Indian Journal of Science and Technology 6(2). 4112-4115.

12. Kamanbedast, A. A. and A. Ghahremani. 2014. Evaluation of scour around bridge pile in flood with hec-ras software. Journal of River Engineering 2, 21(9): 1374-1378.

13. Kaman Bedast, A. A., E. J. Taghi Moheb, M. Shah-Hosseini. 2010. "Flow structural analysis and flow divider structure design at river forks. In: Proceeding of the National Conference on Water Resources, Islamic Azad University of Ahvaz.

14. Lane, S. N., K. F. Bradbrook, K. S. Richards, P. M. Biron and A. G. Roy. 2000. Secondary circulation cells in river channel confluences: measurement artifacts or coherent flow structures. Hydrological Processes 14(11-12): 20472071.

15. Nadri, M., M. H. Erfanian Azmodeh and A. A. Kamanbedast. 2013. The study of water banned at downstream of karkheh river at boundary of hour-ol-azim wetland with using HEC-RAS model. World Applied Sciences Journal 21 (9): 1374-1378.

16. Roozbahani, M. 1989. Detailed Report on Karkheh River's Drainage Basin, Khuzestan Water and Electricity Organization, Department of Water Sources.

17. Shazy. Shabayek, Peter steffler \& Faye Hicks. 2002 Dynamic model for subcritical flows in channel junction. ASCE, 128(9): 821-828. 
18. Taebi, H., M. Shafei Bejestan and M. Straw. Numerical simulation of flow at 90 degrees with CCHE2D model, In: Proceeding of the Eighth International Seminar on River Engineering, Shahid Chamran University, Ahvaz.

19. Zarezadeh, M., M. Shafai Bajestan and A. A. Kamanbedast. 2010. Influence of Building detention and reservoir dams at keeping and rising water level on the grate karoon river, World Applied Sciences Journal 9(10): 1081-1088.

20. Zhang, Y. 2005. CCHE2D-GUI - Graphical User Interface for the CCHE2D Model, User's Manual - Version 2.2, Technical Report No. NCCHE-TR-2005- 03, the University of Mississippi. 


\title{
Experimental Investigation of Flow Hydraulic in the Branch of rivers (A Case Study: Karkheh River)
}

\author{
A. Saki ${ }^{1,2}$, A. A. Kamanbedast ${ }^{2 *}$ A. R. Masjedi ${ }^{2}$, M. Heidarnejad ${ }^{2}$ and A. Bordbar ${ }^{2}$
}

(Received: November 7-2017; Accepted: September 22-2018)

\begin{abstract}
After Hamidieh Diversion Dam near the city of Hamidieh, Karkheh River is divided into two streams known as Hufel and Nissan. At the lower flow rates, Nissan makes up a greater share than Hufel due to the steeper slope of the former. This study attempted to construct a hydraulic structure to appropriately divide water flow in Hufel. In a laboratory experiment, a flume with a 90-degree bend was used at Islamic Azad University of Ahvaz. Various experiments were conducted at different widths and heights. Furthermore, this model was simulated through CCHE2D, the results of which were compared against those of physical and mathematical models. The results indicated that the weir height increased the deviation flow percentage to the Hufel stream due to rising water level. Moreover, the deviation flow percentage to Hufel was declined as the weir width was increased due to falling water level. At Hufel, the installation of rectangular weir in different dimensions yielded the minimum of $34.3 \%$ and the maximum of $61.5 \%$ increase in the flow rate. In the normal mode without any weirs installed, however, there would be an increase in the flow rate, as compared to the mode where a weir has been installed. This can be associated with the flow controlled by the weir. On average, the deviation flow rate was increased by $2.8 \%$ in the weir mode and $7.7 \%$ in the weir-less one. An increase in the Froude number from 0.21 to 0.38 led to a lower average deviation flow rate by $19.3 \%$. Moreover, the results of the simulation through CCHE2D were demonstrated to be largely similar to those of physical model experiments. However, an increase in the Froude number did not lead to a decline in the deviation flow rate (i.e. it remained constant). This trend was inconsistent with the results of the physical model.
\end{abstract}

Keywords: Weir, River branch, Physical model, Mathematical model, CCHE2D

1. Department of Water Science and Engineering, Khouzestan Science and Research Branch, Islamic Azad University, Ahvaz, Iran.

2. Department of Water Science and Engineering, Ahvaz Branch, Islamic Azad University, Ahvaz, Iran.

*: Corresponding Author, Email: Ka57_amir@yahoo.com 